\title{
Chemical characterization of long-range transport biomass burning emissions to the Himalayas: insights from high-resolution aerosol mass spectrometry
}

\author{
Xinghua Zhang ${ }^{1,2,3}$, Jianzhong Xu ${ }^{1}$, Shichang Kang ${ }^{1}$, Yanmei Liu ${ }^{1,3}$, and Qi Zhang ${ }^{4}$ \\ ${ }^{1}$ State Key Laboratory of Cryospheric Sciences, Northwest Institute of Eco-Environment and Resources, \\ Chinese Academy of Sciences, Lanzhou 730000, China \\ ${ }^{2}$ Key Laboratory of Arid Climatic Change and Reducing Disaster of Gansu Province, Key Laboratory of Arid Climatic \\ Change and Disaster Reduction of CMA, Institute of Arid Meteorology, China Meteorological Administration, \\ Lanzhou 730020, China \\ ${ }^{3}$ University of Chinese Academy of Sciences, Beijing 100049, China \\ ${ }^{4}$ Department of Environmental Toxicology, University of California, Davis, CA 95616, USA
}

Correspondence: Jianzhong Xu (jzxu@lzb.ac.cn)

Received: 2 November 2017 - Discussion started: 13 November 2017

Revised: 7 February 2018 - Accepted: 14 February 2018 - Published: 5 April 2018

\begin{abstract}
An intensive field measurement was conducted at a remote, background, high-altitude site (Qomolangma Station, QOMS, $4276 \mathrm{~m}$ a.s.l.) in the northern Himalayas, using an Aerodyne high-resolution time-of-flight aerosol mass spectrometer (HR-ToF-AMS) along with other collocated instruments. The field measurement was performed from 12 April to 12 May 2016 to chemically characterize the high time-resolved submicron particulate matter $\left(\mathrm{PM}_{1}\right)$ and obtain the dynamic processes (emissions, transport, and chemical evolution) of biomass burning (BB), frequently transported from South Asia to the Himalayas during pre-monsoon season. Overall, the average $( \pm 1 \sigma) \mathrm{PM}_{1}$ mass concentration was $4.44( \pm 4.54) \mu \mathrm{g} \mathrm{m}^{-3}$ for the entire study, which is comparable with those observed at other remote sites worldwide. Organic aerosol (OA) was the dominant $\mathrm{PM}_{1}$ species (accounting for $54.3 \%$ of total $\mathrm{PM}_{1}$ on average) followed by black carbon (BC) $(25.0 \%)$, sulfate $(9.3 \%)$, ammonium $(5.8 \%)$, nitrate $(5.1 \%)$, and chloride $(0.4 \%)$. The average size distributions of $\mathrm{PM}_{1}$ species all peaked at an overlapping accumulation mode $(\sim 500 \mathrm{~nm})$, suggesting that aerosol particles were internally well-mixed and aged during long-range transport. Positive matrix factorization (PMF) analysis on the high-resolution organic mass spectra identified three distinct OA factors, including a BB-related OA (BBOA, 43.7\%), a nitrogen-containing $\mathrm{OA}$ (NOA, $13.9 \%$ ) and a more-oxidized oxygenated OA (MO-OOA, $42.4 \%$ ). Two polluted episodes
\end{abstract}

with enhanced $\mathrm{PM}_{1}$ mass loadings and elevated BBOA contributions from the west and southwest of QOMS during the study were observed. A typical BB plume was investigated in detail to illustrate the chemical evolution of aerosol characteristics under distinct air mass origins, meteorological conditions, and atmospheric oxidation processes.

\section{Introduction}

The Tibetan Plateau and Himalayas (TPH), generally called the "third pole", is the highest (average altitude of more than $4000 \mathrm{~m}$ a.s.l.) and largest $\left(\sim 2500000 \mathrm{~km}^{2}\right)$ plateau in the world. This region has been recognized as one of the most pristine in the world due to its high altitude, sparse population, and the minor influence of anthropogenic activities (Yao et al., 2012a). Considering the intense dynamical and thermal forcing effects in this region, the TPH not only plays a key role in the formation of Asian monsoon systems, but also impacts large-scale atmospheric circulation, the hydrological cycle, as well as global climate (Duan and $\mathrm{Wu}, 2005$; Wu et al., 2007). Over the past few decades more attention has been paid to the environment and climate change in the TPH, owing to the fact that this region is very susceptible to global climate change as evidenced by rapid air temperature 

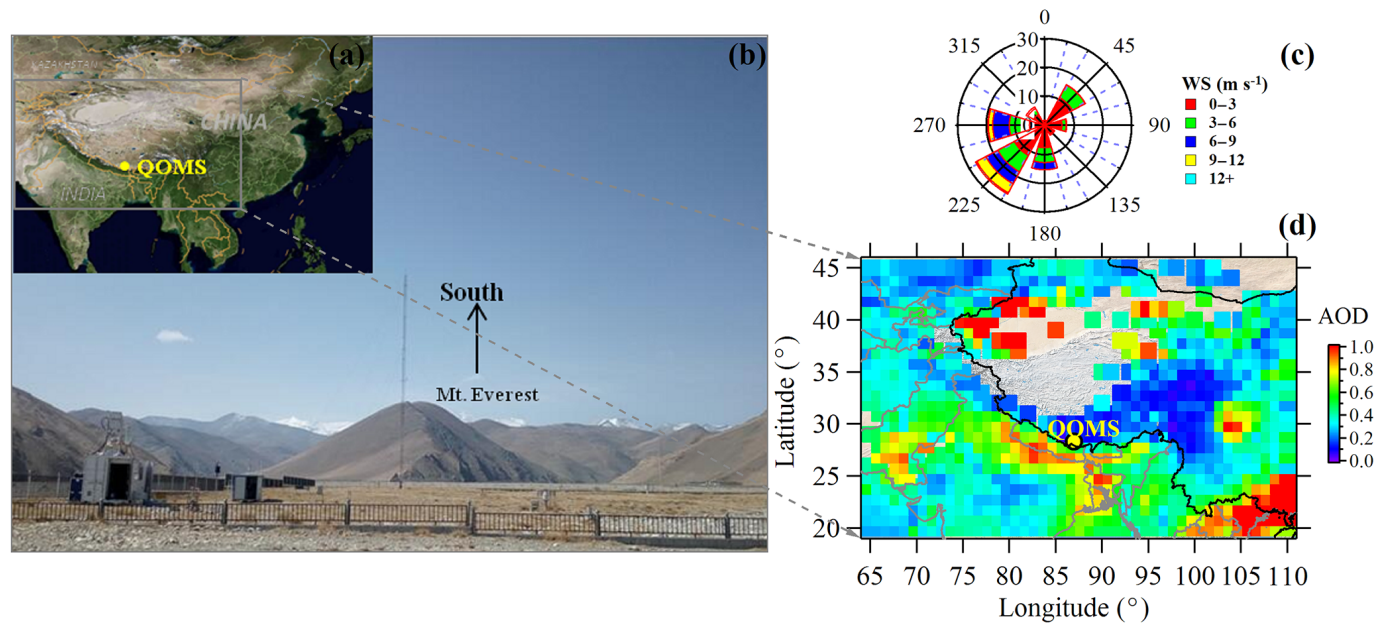

Figure 1. (a) Map of the QOMS location, (b) picture of the QOMS and its surrounding, (c) wind rose plot colored by wind speed in this study, and (d) distribution of the average aerosol optical depth (AOD) around the QOMS retrieved from Terra MODIS at $550 \mathrm{~nm}$ during this study.

increases and dramatic glacier shrinkage (Xu et al., 2009; Kang et al., 2010; Yao et al., 2012b; Yang et al., 2014). The atmospheric environment in the TPH, although it is one of the most pristine regions in the world, is thought to be significantly influenced by air pollution from surrounding countries (Hou et al., 2003; Lau et al., 2008). For example, polluted air masses, particularly from South and Southeast Asia regions, have frequently been observed being transported to the Himalayas (Bonasoni et al., 2010; Cong et al., 2015), heating the aloft air masses over the TPH (Lau et al., 2006; Ramanathan and Carmichael, 2008) and declining the surface albedo after their deposition onto snow and glaciers (Xu et al., 2009). As a consequence, characterizing the aerosol physicochemical properties in the TPH, including mass loading, chemical composition, size distribution, and source, are of great importance to better understanding the aerosol chemistry, estimating the aerosol radiative forcing, and evaluating the effect of polluted air masses on the ecology and environment in the TPH region.

Numerous aerosol measurements have been conducted in the TPH region in past decades to characterize the physicochemical properties, sources, and transport pathways of ambient aerosol (Liu et al., 2008; Decesari et al., 2010; Marcq et al., 2010; Marinoni et al., 2013; Putero et al., 2014; Xu et al., 2018; R. Zhang et al., 2017). South and Southeast Asia are two major polluted regions due to their intense biomass burning (BB) activities from natural forest fires and traditional human burning activities for residential heating and cooking (Engling et al., 2011; Yadav et al., 2017). The average pollutant distribution of South and Southeast Asia during the 12 April to 12 May 2016 period can be further revealed by the distribution of average aerosol optical depth in Fig. 1. During the pre-monsoon period, atmospheric pollutants associated with BB emissions in South Asia are generally advected by regional and long-range transport (e.g., westerlies and South Asian monsoon system) to the Himalayas and build up in the southern foothills, where they are then lifted up to high altitude by the Himalayan topography and typical valley wind circulation (Zhao et al., 2013; Cong et al., 2015; Liu et al., 2017). However, the chemical properties of aerosol particles are still not well understood in the Himalayas region due to its remote and harsh environments, challenging weather conditions, and logistical difficulties. In addition, most available studies are based mainly on off-line filter sampling of ambient aerosol or snow/ice samples followed by laboratory analyses (Decesari et al., 2010; Ram et al., 2010; Li et al., 2016; Wan et al., 2017). These studies have usually had a relatively low temporal resolution (days to weeks); therefore, real-time consecutive field measurement, especially focusing on the high-resolution size-resolved chemical characteristics of aerosol particles, is of great importance and necessary to give insight into the sources and the dynamic chemical evolution of ambient aerosol.

Online real-time instrument such as the Aerodyne aerosol mass spectrometer (AMS), which can be used to characterize the chemical properties and sources of submicron aerosol particles with high time resolution and sensitivity, has been greatly developed and widely implemented worldwide (Canagaratna et al., 2007; Zhang et al., 2007a; Jimenez et al., 2009; Li et al., 2017). Although the deployments of the AMS in China started in 2006, most of the studies in China have been conducted in urban areas, including Beijing-TianjinHebei (Sun et al., 2013, 2016), Yangtze River Delta (Wang et al., 2016a, b), Pearl River Delta regions (Huang et al., 2011), and Lanzhou (Xu et al., 2014, 2016; X. Zhang et al., 2017) as shown in Fig. S1 in the Supplement. However only a few studies have been deployed in remote sites thus far, such as Menyuan (Du et al., 2015), Mt. Yulong (Zheng et al., 2017), 
and Nam Co (Xu et al., 2018; Wang et al., 2017). In this paper, an Aerodyne high-resolution time-of-flight mass spectrometer (HR-ToF-AMS) was deployed at the Qomolangma Station for Atmospheric and Environmental Observation and Research (QOMS) on the northern slope of the Himalayas to fill the vacancy of real-time mass spectrometer measurement at high elevation sites and to evaluate the significant impacts of BBs from polluted areas in southern Asia on TPH aerosol properties during the pre-monsoon season. Here, we report an overview of the $5 \mathrm{~min}$ real-time chemical and physical characteristics of submicron aerosols $\left(\mathrm{PM}_{1}\right)$, including mass loading, composition, size distribution, and acidity as well as temporal and diurnal variations. The sources of organic aerosols (OA) are also investigated using positive matrix factorization analysis on the high-resolution OA mass spectrum. $\mathrm{BB}$ influence and chemical evolution of aerosols in polluted plumes are examined by combining back trajectory analysis of air masses and fire hotspots information.

\section{Experimental methods}

\subsection{Sampling site}

The QOMS ( $28.36^{\circ} \mathrm{N}, 86.95^{\circ}$ E, $4276 \mathrm{~m}$ a.s.l.; Fig. 1), which is located on the northern slope of Mt. Everest $(\sim 30 \mathrm{~km}$ away), was established for atmospheric and environmental observation in 2005 (Ma et al., 2008). The geomorphic and climate features around the QOMS are typically alpine, comprising cold and arid areas covered by sandy soil with sparse vegetation. The QOMS is located in a long river valley and isolated from residential areas due to its harsh environment, with a small village (with a population of $\sim 300$ ) to the south $(\sim 10 \mathrm{~km})$. The closest larger settlement, Dingri County, is $\sim 100 \mathrm{~km}$ south from the QOMS. A freeway is located at the front of the QOMS for tourism with increased tourist during summer. The measurements were conducted from 12 April to 12 May 2016. Since this period was within the typical premonsoon season of the TPH, the large-scale atmospheric circulation pattern was dominated by westerly or southwesterly winds and limited precipitation. Owing to distinct thermal forcing from the southern mountains and glaciers, the QOMS was locally dominated by strongly mountain-valley circulation with down-slope wind prevailing during the daytime, especially in the afternoon (Figs. 1c and S2) (Zou et al., 2008), which made the valley an efficient channel for the downward transport of air masses from the high-altitude troposphere.

\subsection{Instrumentation}

A suite of real-time instruments were collocated to measure the physiochemical properties of fine particles at the QOMS, including an Aerodyne HR-ToF-AMS (Aerodyne Research Inc., Billerica, MA, USA) for 5 min size-resolved chemical compositions (organics, sulfate, nitrate, ammonium, and chloride) of non-refractory submicron particulate matter (NR-PM $)_{1}$ ); a scanning mobility particle sizer (SMPS, model 3936, TSI Inc., Shoreview, MN, USA) for 5 min particle number concentration and size distribution between 14.6 and $661.2 \mathrm{~nm}$ in mobility diameter $\left(D_{\mathrm{m}}\right)$; and a photoacoustic extinctiometer (PAX, DMT Inc., Boulder, CO, USA) for particle light absorption and scattering coefficient $\left(b_{\mathrm{abs}}\right.$ and $\left.b_{\text {scat }}\right)$ at $405 \mathrm{~nm}$ and further deriving black carbon (BC) mass concentration. All instruments were placed in an airconditioned room and the temperature was maintained at $\sim 20^{\circ} \mathrm{C}$. Ambient aerosol particles were introduced through a 0.5 inch copper tube which stemmed about $1.5 \mathrm{~m}$ out of the rooftop. A PM 2.5 cyclone (model URG-2000-30EH, URG Corp., Chapel Hill, NC, USA) was used in front of the sampling inlet for removing coarse particles with size cutoffs of $2.5 \mu \mathrm{m}$ in aerodynamic diameter $\left(D_{\mathrm{va}}\right)$. A diffusion dryer was placed behind the cyclone to dry the ambient air and eliminate the potential effect of humidity on particles. The total length of the sampling line was about $5 \mathrm{~m}$ and the retention time of particles was less than $2.5 \mathrm{~s}$ in the whole inlet. The total air flow rate from the sampling inlet was about $10 \mathrm{~L} \mathrm{~min}^{-1}$, with part of the flow shared by the HR-ToFAMS and the SMPS while the remaining flow exhausted via an external pump. The meteorology data including wind speed (WS), wind direction (WD), relative humidity (RH), temperature $(T)$, and solar radiation (SR) during this study were obtained from a Vantage Pro2 weather station (Davis Instruments Corp., Hayward, CA, USA). Note that all references to date and time in this study are reported in local time (LT), i.e., Beijing time (BJT: UTC $+8 \mathrm{~h}$ ).

\subsection{HR-ToF-AMS operation and data analysis}

\subsubsection{HR-ToF-AMS operation}

A detailed instrumental description of the Aerodyne HRToF-AMS can be found elsewhere (DeCarlo et al., 2006), therefore only a brief summary is provided here. The HRToF-AMS consists of three main parts: an aerosol sampling inlet, a particle sizing vacuum chamber, and a particle composition detection section (Jimenez et al., 2003). Ambient particles are sampled into the instrument through a critical orifice $(130 \mu \mathrm{m}$ in this study for enhancing the transmission efficiency at the high-altitude area) and focused into a concentrated and narrow beam through an aerodynamic lens. Particles are then accelerated into the sizing vacuum chamber and obtain different velocities for particles with different sizes due to the supersonic expansion induced by a pressure difference between the two chambers. Meanwhile, a mechanical chopper with two radial slits located $180^{\circ}$ apart is used to intercept the focused particle, and then the time of flight $(\mathrm{P}-\mathrm{ToF})$ from the chopper to the vaporizer is measured to obtain the aerodynamic size of particles. After passing through the sizing chamber, particles are directed onto a resistively heated surface $\left(\sim 600^{\circ} \mathrm{C}\right)$ under a high vacuum and ionized by a $70 \mathrm{eV}$ electron impact, before finally being de- 
tect by the high-resolution time-of-flight mass spectrometer. In this study, the HR-ToF-AMS was only toggled under the high sensitive V-mode (detection limits $\sim 10 \mathrm{ng} \mathrm{m}^{-3}$ ). Under V-mode operation, the instrument also switched between the mass spectrum (MS) mode and the particle P-ToF mode every $15 \mathrm{~s}$, spending 6 and $9 \mathrm{~s}$ on each, to obtain the mass concentrations and size distributions of the non-refractory species, respectively.

The HR-ToF-AMS was calibrated for ionization efficiency (IE) and particle sizing at the beginning, in the middle, and at the end of this study according to the standard protocols (Jayne et al., 2000). Both the calibrations of IE and particle sizing were performed using mono-dispersed ammonium nitrate particles with nominal diameters of 70-300 nm. Default relative ionization efficiency (RIE) values were assumed in this study as 1.1 for nitrate, 1.3 for chloride, and 1.4 for organics. The RIE values of 3.9 and 4.2 were used for ammonium based on the results of two IE calibrations at the beginning and in the middle of this study, while RIE values of 1.6 and 1.4 were determined similarly for sulfate by using monodispersed ammonium sulfate particles, respectively.

\subsubsection{HR-ToF-AMS data analysis}

The mass concentrations and size distributions of NR-PM species and the ion-speciated mass spectra, composition and elemental composition of organics were determined from the HR-ToF-AMS data using the standard ToF-AMS analysis toolkit SQUIRREL (v1.56) and PIKA (v1.15c) modules written in Igor Pro (Wavemetrics Inc., Lake Oswego, OR, USA). An empirical particle collection efficiency (CE) of 0.5 was used to compensate for the incomplete transmission and detection of particles due to particle bouncing at the vaporizer and partial transmission through the aerodynamic lens, which has been widely used in field studies employing AMS with a dryer installed in front of the inlet (Xu et al., 2014, 2016). The elemental ratios of oxygen-to-carbon $(\mathrm{O} / \mathrm{C})$, hydrogen-to-carbon ( $\mathrm{H} / \mathrm{C})$, nitrogen-to-carbon $(\mathrm{N} / \mathrm{C})$, and organic mass-to-organic carbon $(\mathrm{OM} / \mathrm{OC})$ for this study were determined using the "improved-ambient" method (referred as I-A method) (Canagaratna et al., 2015), which increased $\mathrm{O} / \mathrm{C}$ on average by $34 \%, \mathrm{H} / \mathrm{C}$ on average by $15 \%$, and $\mathrm{OM} / \mathrm{OC}$ on average by $17 \%$ (Fig. S3) compared with those determined from the "Aiken ambient" method (referred as A-A method) (Aiken et al., 2008).

Positive matrix factorization (PMF) analysis using the PMF2.exe algorithm (v4.2) (Paatero and Tapper, 1994) in robust mode was conducted on the high resolution mass spectra (HRMS) to determine distinct OA components in this study. The analysis was performed using an Igor Pro-based PMF Evaluation Tool (PET, v2.03) (Ulbrich et al., 2009), downloaded from (http://cires.colorado.edu/jimenez-group/ wiki/index.php/PMF-AMS_Analysis_Guide). The data and error matrices input into the PMF analysis were generated from analyzing the V-mode data via PIKA fitting. Detailed
PMF analysis was thoroughly evaluated following the procedures summarized in Table 1 of Zhang et al. (2011). Isotopic ions were generally excluded and the four ions of $\mathrm{O}^{+}, \mathrm{HO}^{+}$, $\mathrm{H}_{2} \mathrm{O}^{+}$, and $\mathrm{CO}^{+}$were down-weighted in the PMF analysis, because they were determined according to the relationship with $\mathrm{CO}_{2}^{+}$signal (Ulbrich et al., 2009). The "bad" ions with $\mathrm{S} / \mathrm{N}$ less than 0.2 were removed from the HRMS data and error matrices before PMF analysis, and "weak" ions with $\mathrm{S} / \mathrm{N}$ between 0.2 and 2 were down-weighted by increasing their errors. In addition, some runs with huge mass loading spikes were also removed from the data and error matrices. The detailed matrix preparation and data pretreatment can also found in $\mathrm{Xu}$ et al. (2014).

A summary of key diagnostic plots of the PMF results for this study is presented in Fig. S4. Overall, the PMF solutions were investigated for one to eight factors and for the rotational parameter (fPeak) varying from -1 to 1 with a step of 0.1. Besides examining the model residuals, scaled residuals, and the $Q / Q_{\exp }$ contributions for each $\mathrm{m} / z$ and time following procedures detailed in Table 1 of Zhang et al. (2011), the optimum solution can also be evaluated by comparing the mass spectra of individual factors with reference spectra from specific sources or other ambient AMS measurements; comparing the time series of individual factors with the known external tracers; and analyzing the diurnal variations of individual factors. Finally, the three-factor solution with $\mathrm{fPeak}=0$ was chosen in this work. The direct comparisons of the mass spectra, time series, and diurnal variations for two-factor and four-factor solutions were also shown in Figs. S5 and S6, respectively. The two-factor solution does not resolve the small, yet distinct nitrogen-containing OA, while the four-factor solution shows a splitting factor from the BB OA resolved in the three-factor solution and seems just like a simple separation of the two BB polluted episodes.

\subsection{Other relevant data}

The Hybrid Single Particle Lagrangian Integrated Trajectory (HYSPLIT4) model developed by the National Oceanic and Atmospheric Administration (NOAA) (Draxler and Rolph, 2003) was used to investigate the origins of air masses in this study, using the meteorological data from the NOAA Global Data Assimilation System (GDAS). The back trajectories were calculated every $6 \mathrm{~h}$ at an ending height of 500 ma.g.l. (above ground level) at the QOMS during the entire campaign, and then clustered according to similarity in spatial distribution. Finally, a four-cluster solution was adopted according to its small total spatial variance.

Aerosol optical depth (AOD) at $550 \mathrm{~nm}$ was derived from the observations made by National Aeronautics and Space Administration (NASA) Moderate Resolution Imaging Spectroradiometer (MODIS) onboard the Terra satellite. The distribution of average aerosol optical depth (AOD) in a large area $\left(20-45^{\circ} \mathrm{N}, 60-110^{\circ} \mathrm{E}\right)$ around the TPH during the entire period of this study is given in Fig. 1d. 


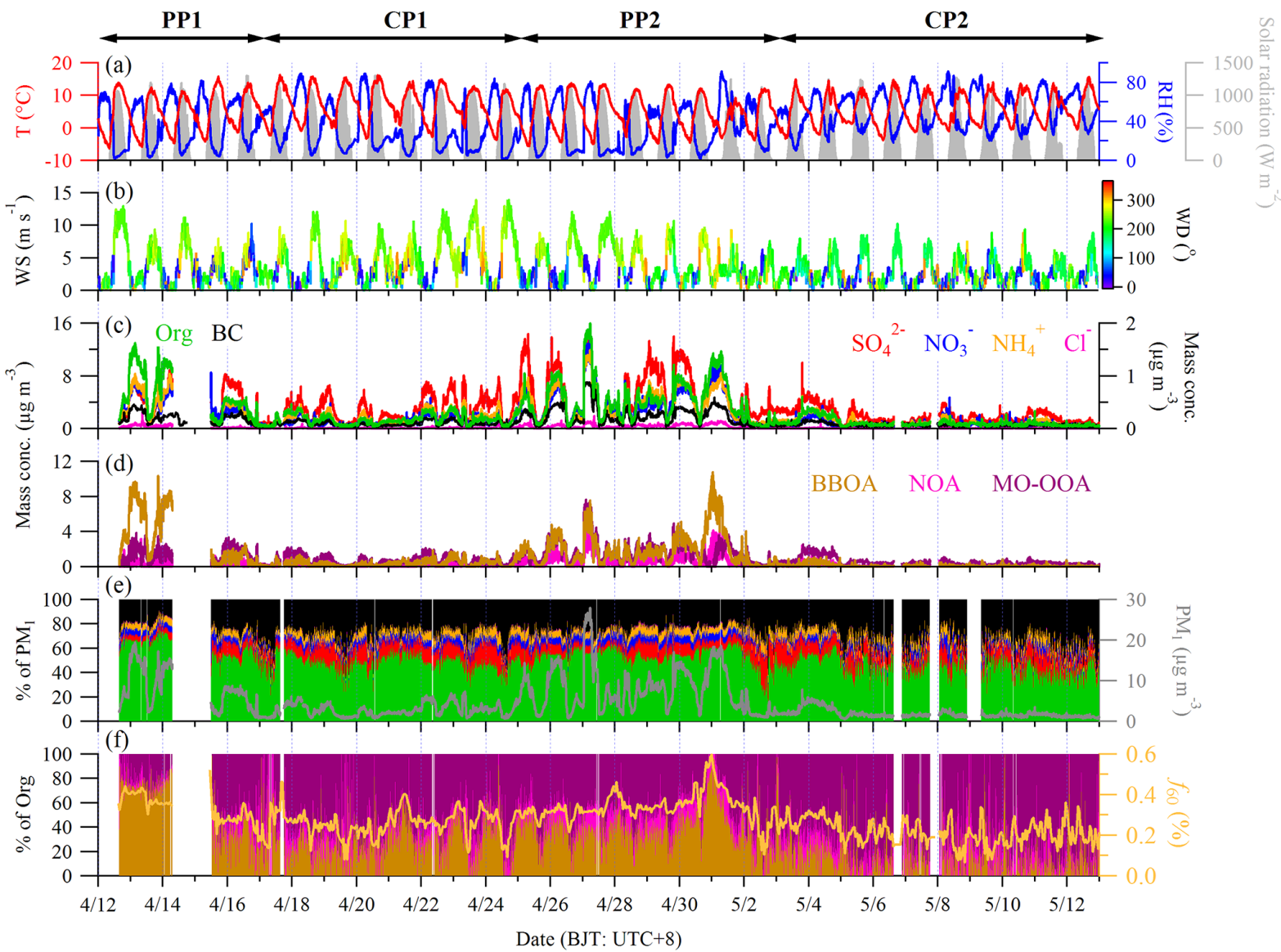

Figure 2. Summary of meteorological and HR-ToF-AMS data. The 5 min time series of (a) ambient temperature $(T)$, relative humidity (RH), and solar radiation, (b) wind speed (WS) colored by wind direction (WD), (c) mass concentrations of PM $_{1}$ species, (d) mass concentrations of organic components, (e) mass contributions of $\mathrm{PM}_{1}$ species to total $\mathrm{PM}_{1}$ as well as total $\mathrm{PM}_{1}$ mass concentrations, and (f) mass contributions of organic components to organics. The time series of hourly average $f_{60}\left(=\mathrm{C}_{2} \mathrm{H}_{4} \mathrm{O}_{2}^{+} / \mathrm{OA}\right)$ values for the entire period is also shown. The markers of PP1 and PP2 represent the two polluted periods while CP1 and CP2 are clear periods.

Various active fire hotspots were detected over South and Southeast Asia by the Fire Information for Resource Management System (FIRMS) provided by the MODIS satellite (https://firms.modaps.eosdis.nasa.gov), demonstrating the possibility that active wildfires or BBs from South and Southeast Asia may have significant impacts on the air conditions in the TPH region.

The aerosol liquid water content (ALWC) was estimated with the Extended AIM (E-AIM) Aerosol Thermodynamics Model (http://www.aim.env.uea.ac.uk/aim/aim.php). The input data included the concentrations of sulfate, nitrate, ammonium, and chloride measured by the HR-ToF-AMS as well as the relative humidity (RH) and temperature of ambient air.

\section{Results and discussion}

\subsection{Overview of the study}

\subsubsection{Meteorological conditions}

The measurement period of our study was within the typical pre-monsoon season of the TPH. The meteorological conditions were therefore characterized by relatively cold, dry, and windy weather, and the westerlies dominated largescale atmospheric circulation patterns with little precipitation, as displayed in Fig. 2. During the study, the averaged diurnal air temperature ranged from -2.0 to $12.5^{\circ} \mathrm{C}$ with an average $( \pm 1 \sigma)$ of $5.7( \pm 5.0)^{\circ} \mathrm{C}$, and the $\mathrm{RH}$ ranged from 15.3 to $67.5 \%$ with an average of $39.8 \pm 18.8 \%$. Only two light precipitation events $\left(1\right.$ and $0.5 \mathrm{~mm} \mathrm{day}^{-1}$ ) occurred on 1 and 8 May, respectively. The WDs at QOMS were predominantly southwesterly, which were mainly associated with the thermally driven mountain-valley winds and glacier winds (Zou et al., 2008). For the diurnal variation of wind condi- 
tions, a nearly calm wind period (hourly average WS less than $2 \mathrm{~m} \mathrm{~s}^{-1}$ ) was observed in the early morning; after sunrise until noon, there was a weak up-slope wind period (from the north); the diurnal wind cycles were otherwise dominated by down-slope wind (from the southwest) with a maximum hourly average WS value of up to $7 \mathrm{~m} \mathrm{~s}^{-1}$ (Figs. $2 \mathrm{~b}$ and S2).

\subsubsection{Inter-comparisons between different instruments}

An inter-comparison of the total $\mathrm{PM}_{1}\left(\mathrm{NR}-\mathrm{PM}_{1}+\mathrm{BC}\right)$ mass concentrations measured by the HR-ToF-AMS $(\mathrm{CE}=0.5)$ and the PAX with particle volumes (assuming spherical particles) determined from the SMPS is shown in Fig. S7. Overall, the $\mathrm{PM}_{1}$ mass is closely correlated $\left(R^{2}=0.97\right)$ with that of SMPS particle volume during the entire campaign, with a linear regression slope of 2.86. This slope is significantly higher than the estimated average $\mathrm{PM}_{1}$ density of $1.44 \mathrm{~g} \mathrm{~cm}^{-3}$, which is calculated based on the measured particle compositions in this study and the assumed particle densities of 1.2 for organics, 1.78 for $\left(\mathrm{NH}_{4}\right)_{2} \mathrm{SO}_{4}, 1.72$ for $\mathrm{NH}_{4} \mathrm{NO}_{3}, 1.52$ for $\mathrm{NH}_{4} \mathrm{Cl}$, and $1.8 \mathrm{~g} \mathrm{~cm}^{-3}$ for $\mathrm{BC}$ (Zhang et al., 2005b; Xu et al., 2016). This discrepancy is likely introduced by various factors, including different transmission sizes between HR-ToF-AMS and SMPS (up to $\sim 1.0 \mu \mathrm{m}$ in $D_{\text {va }}$ for AMS vs. limited size range of $14.6-661.2 \mathrm{~nm}$ in $D_{\mathrm{m}}$ for SMPS), rough calculation of $\mathrm{PM}_{1}$ density using assumed composition densities and spherical shape without considering the particle porosity, as well as the use of the empirical and constant CE value of 0.5 in this study. This phenomenon was also observed at other sites in previous studies (Ge et al., 2012; Huang et al., 2012; Xu et al., 2014; Du et al., 2015).

\subsubsection{Mass concentration and chemical composition of $\mathbf{P M}_{1}$}

As shown in Fig. 2, the mass concentrations of $\mathrm{PM}_{1}$ and all $\mathrm{PM}_{1}$ species, as well as their mass fractions in $\mathrm{PM}_{1}$ varied dynamically throughout this study. Two polluted periods (PP1 and PP2) were identified according to their high $\mathrm{PM}_{1}$ mass concentrations (daily average $\mathrm{PM}_{1}$ mass is larger than $5 \mu \mathrm{g} \mathrm{m}^{-3}$ ), high contributions from BBOA and unique back trajectories. The rest periods characterized by low $\mathrm{PM}_{1}$ mass concentrations were considered as clear periods (CP1 and $\mathrm{CP} 2$ ). The $5 \mathrm{~min}$ total $\mathrm{PM}_{1}$ mass concentration ranged from 0.18 to $27.97 \mu \mathrm{g} \mathrm{m}^{-3}$ for the study, with an average $( \pm 1 \sigma)$ value of $4.44 \pm 4.54 \mu \mathrm{g} \mathrm{m}^{-3}$. This average value was more than two times lower than most of the $\mathrm{PM}_{1}$ mass concentrations measured with Aerodyne AMS or aerosol chemical speciation monitor (ACSM) instruments at various urban, suburban, rural, or background sites in China (10.9$138.8 \mu \mathrm{g} \mathrm{m}^{-3}$ ) (Fig. S1); however only slightly lower than that at Mt. Yulong $\left(5.7 \mu \mathrm{g} \mathrm{m}^{-3}\right)$ located at the southeastern edge of the TPH, and much higher than that at Nam Co Station $\left(2.0 \mu \mathrm{g} \mathrm{m}^{-3}\right)$ located in the central of the TPH. More-

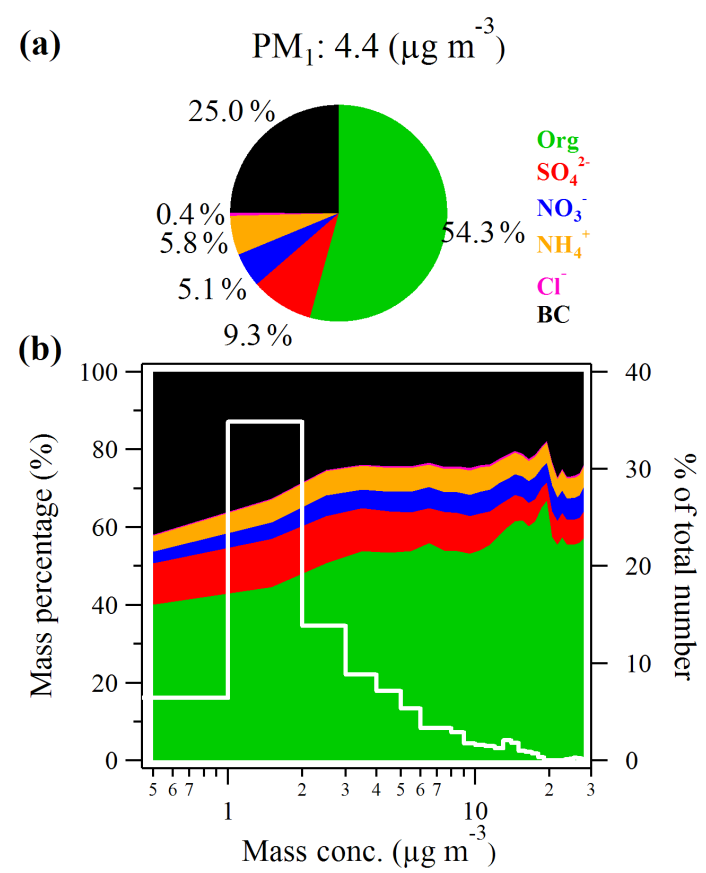

Figure 3. The average mass contributions of $\mathrm{PM}_{1}$ (calculated by NR-PM $1+\mathrm{BC}$ ) species (a) during the entire sampling period and (b) as a function of the total $\mathrm{PM}_{1}$ mass concentrations. The white solid line in (b) shows the percentage of the data number in each mass bin to the total data number.

over, as shown in Table $\mathrm{S} 1$ in the Supplement, the $\mathrm{PM}_{1}$ mass concentration in this study was also lower than those measured at three remote island sites in Asia which were frequently influenced by outflow from China, Korea, and Japan (i.e., $7.9 \mu \mathrm{g} \mathrm{m}^{-3}$ for Okinawa island, $12.0 \mu \mathrm{g} \mathrm{m}{ }^{-3}$ for Fukue island in Japan, and $10.7 \mu \mathrm{g} \mathrm{m}^{-3}$ for Jeju island in Korea) (Takami et al., 2005; Jimenez et al., 2009), as well as the $\mathrm{PM}_{1}$ mass concentration $\left(15.1 \mu \mathrm{g} \mathrm{m}^{-3}\right)$ obtained at the Bachelor Mountain in US which was heavily impacted by wildfire smoke plumes (Zhou et al., 2017). However, it was higher than those reported at other coastal, high elevation, forest, or remote background sites in North America and Europe (0.55-2.91 $\mathrm{\mu g} \mathrm{m}^{-3}$ ) (Zhang et al., 2007a; Sun et al., 2009; Fröhlich et al., 2015). Although the measurements mentioned above were conducted at various sites worldwide during different seasons, these comparisons further demonstrate that QOMS is a typical high elevation, remote, background site in Asia.

Overall, organics and $\mathrm{BC}$ were the two dominant $\mathrm{PM}_{1}$ species ( contributing 54.3 and $25.0 \%$ on average to the total $\mathrm{PM}_{1}$ mass, respectively) followed by sulfate $(9.3 \%)$, ammonium $(5.8 \%)$, nitrate $(5.1 \%)$, and chloride $(0.4 \%)$ (Fig. 3a). The high contributions of organics and $\mathrm{BC}$ at QOMS were significantly associated with the active $\mathrm{BB}$ emissions by long-range transport from polluted areas in South Asia. Organic compounds and $\mathrm{BC}$ have been revealed as two dominant components of $\mathrm{BB}$ aerosols and have generally been 
used to identify BB events in previous studies (Bond et al., 2004; Bougiatioti et al., 2014). In addition, biomass burning at high elevation regions of the Himalayas and southern Asia was more incomplete burning and had the potential to emit high amounts of BC. This conclusion can be further revealed by their enhanced mass concentrations and contributions, especially for organics, during the two distinct polluted episodes influenced by active BB plumes. Figure $3 \mathrm{~b}$ showed the mass contributions of $\mathrm{PM}_{1}$ species as a function of total $\mathrm{PM}_{1}$ mass concentrations. The $\mathrm{PM}_{1}$ mass loadings in this study were mostly below $6 \mu \mathrm{g} \mathrm{m}^{-3}$ (accounted for $\sim 77 \%$ ); The mass contribution of organics increased significantly with the increase of total $\mathrm{PM}_{1}$ mass loading whereas the rest species showed relatively stable or decrease trends, suggesting dominant contributions of organics in the polluted episodes at QOMS.

\subsubsection{Acidity and size distributions of submicron aerosols}

To evaluate the bulk acidity of NR-PM 1 in this study, we calculated the $\mathrm{NH}_{4}^{+}$concentration $\left(\mathrm{NH}_{4 \text { calc }}^{+}\right)$based on the mass concentrations of sulfate, nitrate, and chloride measured by the HR-ToF-AMS and assumed full neutralization of these anions by ammonium (Zhang et al., 2007b). The scatter plot of the measured $\mathrm{NH}_{4}^{+}\left(\mathrm{NH}_{4 \text { meas }}^{+}\right)$concentration vs. the $\mathrm{NH}_{4 \text { calc }}^{+}$concentration for the entire campaign was shown in Fig. S7. A tight correlation $\left(R^{2}=0.97\right)$ existed between $\mathrm{NH}_{4 \text { meas }}^{+}$and $\mathrm{NH}_{4 \text { calc }}^{+}$with a linear regression slope of 1.2, indicating that there were excesses of ammonium in the submicron particle. This slightly high $\mathrm{NH}_{4 \text { meas }}^{+} / \mathrm{NH}_{4 \text { calc }}^{+}$ ratio was quite different to results from various urban and rural sites in China, where bulk aerosols were neutralized overall or acidic due to the enriched gaseous precursors of $\mathrm{SO}_{2}$ and $\mathrm{NO}_{x}$ which could be further oxidized to sulfate and nitrate (Sun et al., 2013; Xu et al., 2014; Du et al., 2015; X. Zhang et al., 2017). The excess ammonium at QOMS might relate to the important contributions of organic acids in this area (Cong et al., 2015), which could underestimate the $\mathrm{NH}_{4 \text { calc }}^{+}$due to the neglect of organic acids in the ion-balance calculation, and the non-negligible contributions of nitrogencontaining organic compounds to $\mathrm{NH}_{x}^{+}$which finally overestimated the $\mathrm{NH}_{4 \text { meas }}^{+}$(Sun et al., 2009; Ge et al., 2012). As mentioned above, atmospheric aerosols in the TPH region were significantly influenced by BB emissions from South Asia during the sampling periods. BBs would emit large amounts of nitrogen-containing organic compounds (Fleming et al., 2018; Zhou et al., 2017) and as discussed in Sect. 3.2.

Figure 4 shows the average size distributions of NR$\mathrm{PM}_{1}$ species and their mass contributions as the function of size distribution. Overall, all chemical species showed a nearly consistent but narrow accumulation mode peaking at $\sim 500 \mathrm{~nm}$ in $D_{\text {va }}$, indicating the well internal-mixed and aged aerosol particles at QOMS. Ultrafine particles (parti-
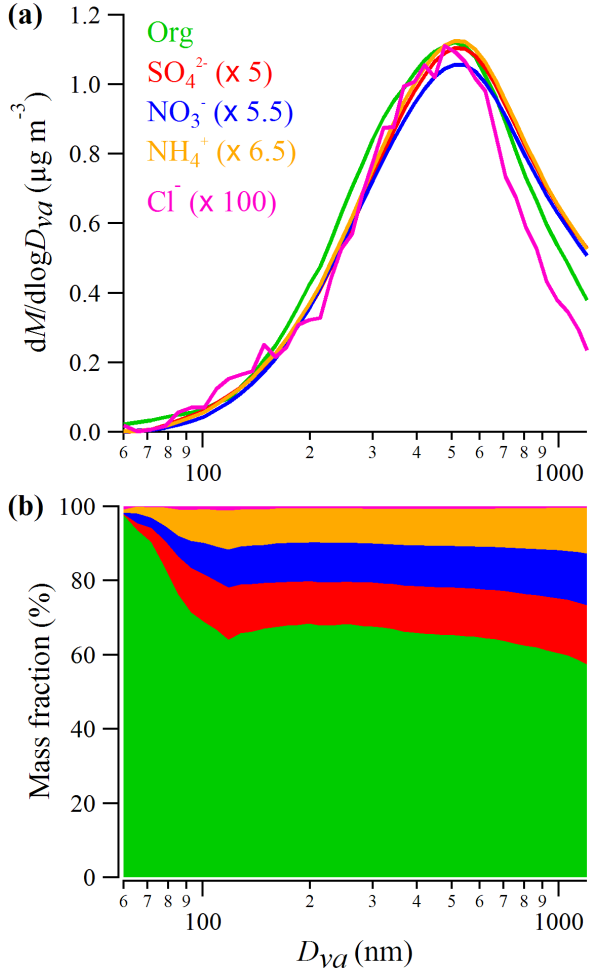

Figure 4. The average size distributions of (a) mass concentrations and (b) mass contributions of NR-PM 1 species for the entire study.

cles with diameter less than $100 \mathrm{~nm}$ ) were dominated by organics (more than $70 \%$ ), while the mass contributions of chemical species at the major peak $(\sim 500 \mathrm{~nm})$ were organics $(\sim 65 \%)$, sulfate $(\sim 13 \%)$, nitrate $(\sim 11 \%)$, ammonium $(\sim 10 \%)$, and chloride $(\sim 1 \%)$. The contribution of organics decreased with the increase of size mode, while the contributions of three major inorganic species (sulfate, nitrate, and ammonium) slightly increased with the increasing sizes (Fig. 4b).

\subsubsection{Diurnal variations of chemical species}

The average diurnal cycles of meteorological parameters as well as the $\mathrm{PM}_{1}$ species and their mass fractions for the entire campaign are shown in Fig. 5. All $\mathrm{PM}_{1}$ species presented a similar diurnal pattern with lower concentrations in the daytime and higher concentrations at nighttime. The mass concentrations reached their minimum values at around 15:00. This pattern was accompanied by enhanced wind speed and increased air temperature in the afternoon, which could related to the dynamics of the planetary boundary layer (PBL). After that, the mass concentrations began to build up and reached high levels at nighttime. Note that the mass concentrations of chloride and $\mathrm{BC}$ also displayed a slight peak during the early morning, which corresponded with calm wind conditions and the lowest air temperature of the day; this could also be associated with the enhanced local emissions 
(a)

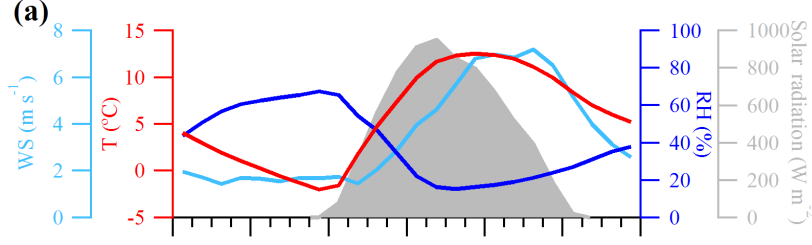

(b)

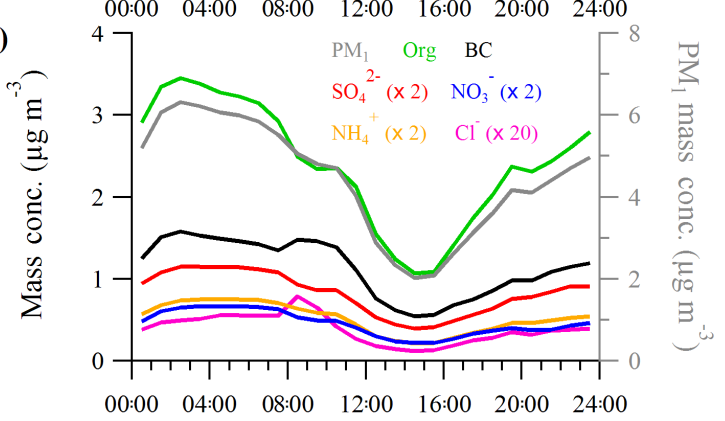

(c)

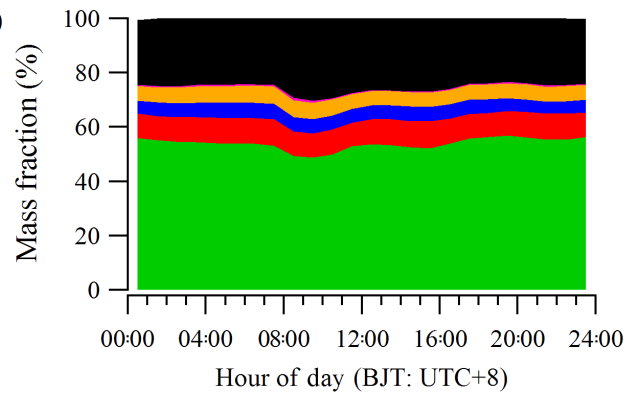

Figure 5. The diurnal cycles of (a) meteorological parameters (temperature, $\mathrm{RH}$, wind speed, and solar radiation), (b) mass concentrations and (c) mass contributions of $\mathrm{PM}_{1}$ chemical species for the entire study.

at QOMS in the morning. The diurnal cycles of mass contributions of each $\mathrm{PM}_{1}$ species were relatively stable for the entire campaign, besides the slight increase of BC from $24 \%$ at $\sim$ 08:00 LT to $30 \%$ at $\sim 10: 00 \mathrm{LT}$. Overall, organics dominated $\mathrm{PM}_{1}$ throughout the day (49-57\%), followed by $\mathrm{BC}$ $(23-30 \%)$, sulfate $(9-10 \%)$, ammonium (5-6\%), nitrate (4$6 \%)$, and chloride $(0.3-0.8 \%)$.

\subsection{Bulk characteristics of $\mathrm{OA}$}

Figure $6 \mathrm{a}$ and $\mathrm{b}$ showed the average mass contributions of the four elements and the six ion categories to total organics, respectively. The organic mass was on average composed of $36.8 \%$ carbon, $57.9 \%$ oxygen, $4.0 \%$ hydrogen, and $1.3 \%$ nitrogen. For ionic categories, $\mathrm{C}_{x} \mathrm{H}_{y} \mathrm{O}_{1}^{+}$ ions dominated the total OA accounting for $41.3 \%$, followed by $\mathrm{C}_{x} \mathrm{H}_{y} \mathrm{O}_{2}^{+}(24.9 \%), \mathrm{C}_{x} \mathrm{H}_{y}^{+}(23.9 \%), \mathrm{H}_{y} \mathrm{O}_{1}^{+}(6.1 \%)$, $\mathrm{C}_{x} \mathrm{H}_{y} \mathrm{~N}_{p}^{+}(2.9 \%)$ and $\mathrm{C}_{x} \mathrm{H}_{y} \mathrm{O}_{z} \mathrm{~N}_{p}^{+}(0.9 \%)$. The contributions of oxygen and the two major oxygenated ion fragments $\left(\mathrm{C}_{x} \mathrm{H}_{y} \mathrm{O}_{z}^{+}=\mathrm{C}_{x} \mathrm{H}_{y} \mathrm{O}_{1}^{+}+\mathrm{C}_{x} \mathrm{H}_{y} \mathrm{O}_{2}^{+}\right)$at QOMS were quite a bit higher than those obtained at other urban or rural sites in China, whereas carbon and $\mathrm{C}_{x} \mathrm{H}_{y}^{+}$ions had relative lower contributions, e.g., $38 \%$ of $\mathrm{C}_{x} \mathrm{H}_{y} \mathrm{O}_{z}^{+}$and $21 \%$ of oxygen vs. $56 \%$ of $\mathrm{C}_{x} \mathrm{H}_{y}^{+}$and $70 \%$ of carbon in urban Lanzhou (Xu et al., 2014), and $37.4 \%$ of $\mathrm{C}_{x} \mathrm{H}_{y} \mathrm{O}_{z}^{+}$vs. $51.2 \%$ of $\mathrm{C}_{x} \mathrm{H}_{y}^{+}$ in urban Nanjing (Wang et al., 2016a), suggesting that OA at QOMS were highly aged. Correspondingly, the average highresolution OA mass spectrum (Fig. 6c) also showed significantly high contribution $(\sim 25 \%)$ at $m / z 44$ signal (one of the most reliable marker of oxygenated OA) compared with other ion fragments, e.g., $5 \%$ at $\mathrm{m} / z 43$ (indicator for less oxidized compounds), $1.7 \%$ at $m / z 55$ (important COA fragment), and $0.4 \%$ at $m / z 57$ (tracer for traffic-related emission) (Alfarra et al., 2004; Zhang et al., 2005a). The average $\mathrm{O} / \mathrm{C}$ ratio was 1.07 during this study, which was much higher than those observed at various urban and rural sites in China using the I-A method, e.g., 0.37 in Beijing (Sun et al., 2016), 0.36 in Lanzhou (Xu et al., 2016), 0.35 in Nanjing (Wang et al., 2016a), and 0.65 in Ziyang (Hu et al., 2016). Moreover, the average $\mathrm{O} / \mathrm{C}$ ratio was even higher than that of 0.98 from the background site of Mt. Wuzhi in southern China (Zhu et al., 2016), indicating that OA at QOMS was more oxidized and aged during long-range transport. The average $\mathrm{H} / \mathrm{C}, \mathrm{N} / \mathrm{C}$ and $\mathrm{OM} / \mathrm{OC}$ ratios were, on average, $1.29,0.026$, and 2.55 in this study, determined by a nominal chemical formula of OA as $\mathrm{C}_{1} \mathrm{H}_{1.29} \mathrm{O}_{1.07} \mathrm{~N}_{0.026}$.

For the diurnal cycles, the $\mathrm{O} / \mathrm{C}$ ratio had two peaks one in the early morning and one in the late afternoon, likely related to the production of secondary organic aerosol (SOA) via aqueous-phase reactions or photochemical oxidation processes during these two periods. $\mathrm{H} / \mathrm{C}$ and $\mathrm{N} / \mathrm{C}$ ratios, however, showed inverse diurnal cycles compared with $\mathrm{O} / \mathrm{C}$, peaking at around 08:00-10:00 LT in the morning. The Van Krevelen diagram ( $\mathrm{H} / \mathrm{C}$ vs. $\mathrm{O} / \mathrm{C})$, which has been widely used to probe the oxidation reaction mechanisms for bulk OA (Heald et al., 2010), showed an apparent inverse correlation $\left(R^{2}=0.57\right)$ with a slope of -0.48 at QOMS (Fig. S8). Ng et al. (2011b) have suggested that a slope of -0.5 indicates a net change in chemical composition from the addition of both acid and alcohol/peroxide functional groups without fragmentation, and/or carboxylic acid groups with fragmentation.

\subsection{Organic aerosol source apportionment}

Source apportionment via PMF analysis on the highresolution OA mass spectrum identified three distinct factors in this campaign according to their unique temporary variations, mass spectrum (MS) profiles, element ratios, correlations with tracers, and diurnal patterns, i.e., a BB-related OA (BBOA), a nitrogen-containing OA (NOA) and a moreoxidized oxygenated OA (MO-OOA). Detailed discussion on each factor is given in the following subsections. 
(a)
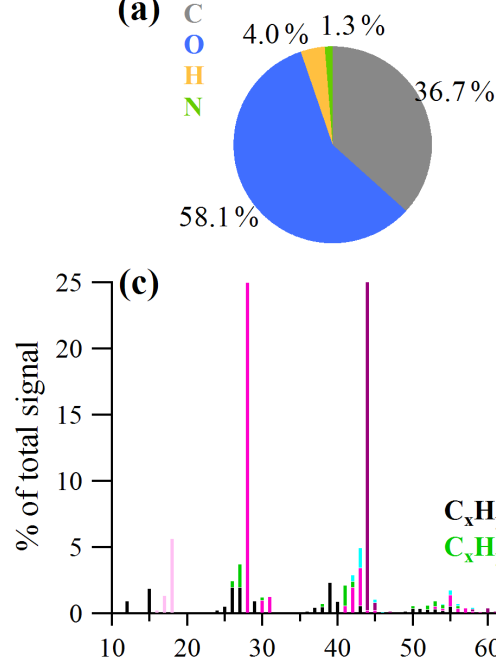

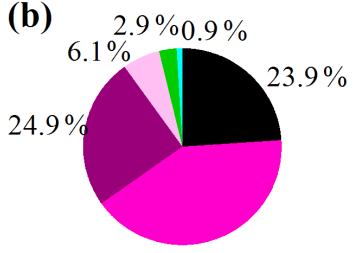

$41.3 \%$

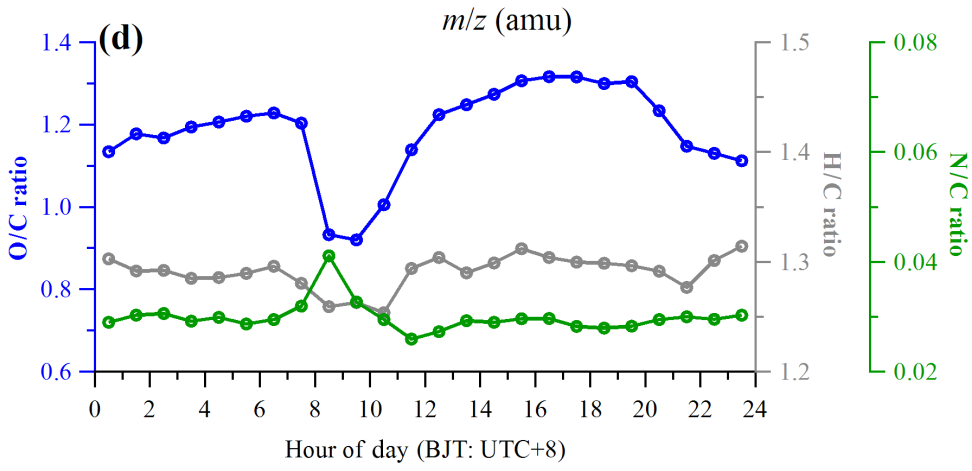

Figure 6. The average contributions of (a) four elements $(\mathrm{C}, \mathrm{O}, \mathrm{H}$, and $\mathrm{N})$ and (b) six ion categories (colors as in c) to OA for the entire study; (c) the average high-resolution mass spectrum of OA (colors show six ion categories); (d) the diurnal variations of $\mathrm{O} / \mathrm{C}$, $\mathrm{H} / \mathrm{C}$, and $\mathrm{N} / \mathrm{C}$ ratios.

\subsubsection{BBOA}

Although significant high contribution at $m / z 44$ (mostly $\mathrm{CO}_{2}^{+}$) was found in all of the three OA components, the BBOA MS was also characterized by contributions at $m / z 60$ (mainly $\mathrm{C}_{2} \mathrm{H}_{4} \mathrm{O}_{2}^{+}$) and $m / z 73$ (mainly $\mathrm{C}_{3} \mathrm{H}_{5} \mathrm{O}_{2}^{+}$) (Fig. $7 \mathrm{~g}$ ), which were generally regarded as well-known tracers for $\mathrm{BB}$ emissions (Alfarra et al., 2007). The average fraction of the signal at $m / z 60$ (referred as $f_{60}$ ) in the BBOA mass spectrum was $0.61 \%$, which was higher than the typical value of $\sim 0.3 \%$ in the absence of BB impacts (Cubison et al., 2011). The time series of BBOA correlated tightly with those of $\mathrm{C}_{2} \mathrm{H}_{4} \mathrm{O}_{2}^{+}\left(R^{2}=0.91\right)$ and $\mathrm{C}_{3} \mathrm{H}_{5} \mathrm{O}_{2}^{+}\left(R^{2}=0.87\right)$ as well as BC $\left(R^{2}=0.72\right)$ and nitrate $\left(R^{2}=0.75\right)$ (Fig. 7a and Table S2). When the influence of high contribution at $m / z 44$ was ignored, the BBOA mass spectrum in this study correlated well $\left(R^{2}=0.5-0.9\right)$ with BBOA mass spectrum identified at other sites worldwide (Ng et al., 2011a; Mohr et al., 2012; Saarikoski et al., 2012; Crippa et al., 2013, 2014; Xu et al., 2016), as shown in Fig. S9. The average mass concentration of BBOA was $1.05 \mu \mathrm{g} \mathrm{m}^{-3}$ for the entire study and con- tributed a large fraction (43.7\%) of the total OA mass on average (Fig. 8a), indicating that BBOA was an important component of OA during the pre-monsoon season at the QOMS. The diurnal cycle of BBOA showed high concentrations during nighttime whereas relatively low concentrations were found during daytime (Fig. 7d). Correspondingly, the mass contributions of BBOA to total OA mass decreased distinctly from $\sim 55 \%$ at 00:00 LT to $28 \%$ at 15:00 LT (Fig. 8b). In addition, higher mass concentrations and contributions of BBOA were found during the two polluted episodes (PP1 and PP2) than those recorded during the clear periods, further indicating the important contribution of BBOA to OA in this region. Figure $8 \mathrm{c}$ showed the mass fractions of the three OA components as a function of total OA mass during the entire campaign. A continuously increased trend was found for the BBOA contributions with the increasing OA mass, which contributed $\sim 15 \%$ when the total OA mass was less than $0.3 \mu \mathrm{g} \mathrm{m}^{-3}$, whereas it reached up to more than $75 \%$ with the OA mass increased to $9 \mu \mathrm{g} \mathrm{m}^{-3}$. This dominant contribution of BBOA during the polluted periods was consistent with results from previous studies which showed that $\mathrm{BB}$ emission 

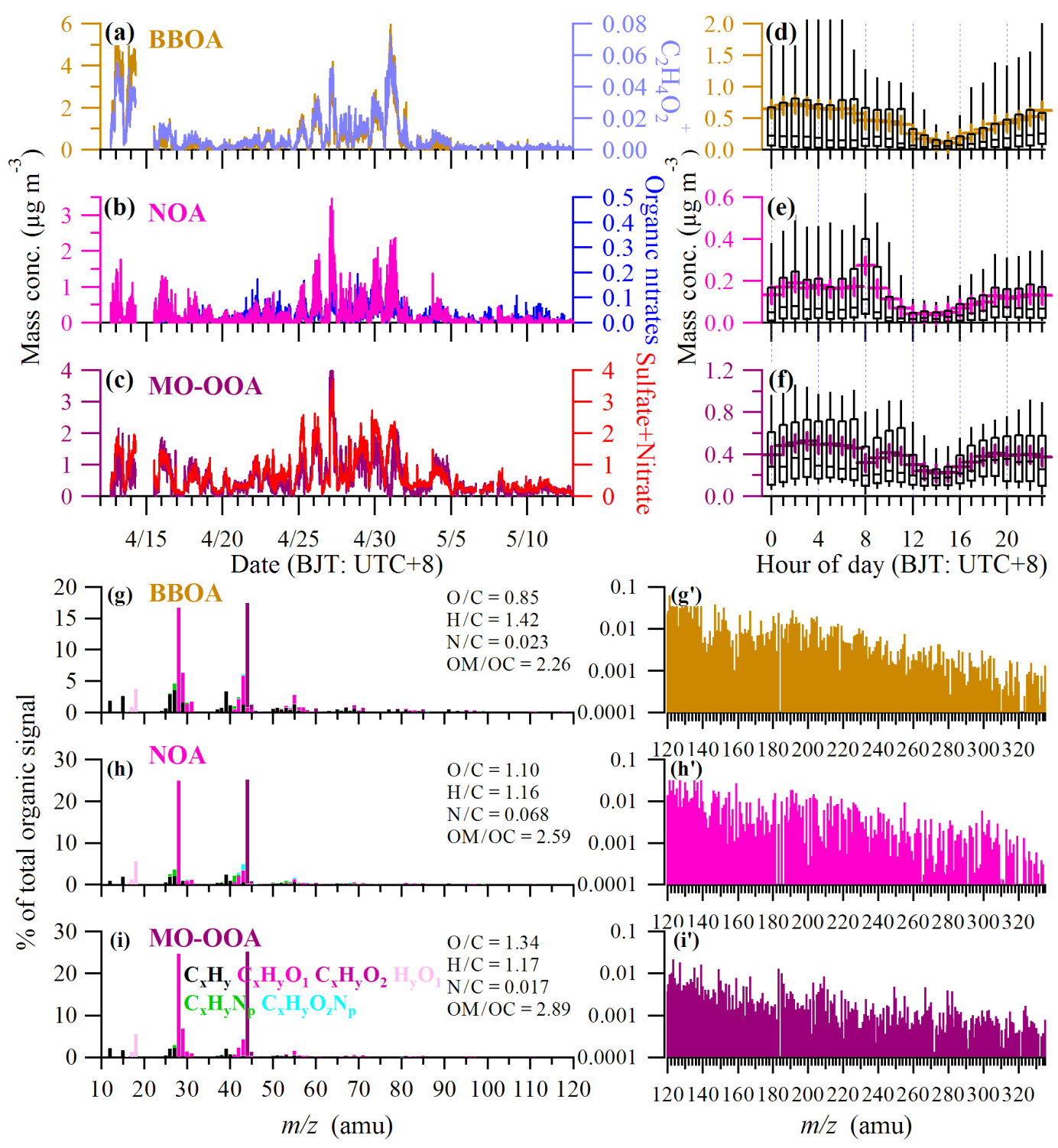

Figure 7. The PMF results of (a)-(c) the time series of three OA factors and corresponding tracer species, (d)-(f) the diurnal variations of the mass concentrations of the three OA factors (the whiskers above and below the boxes indicate the 90th and 10th percentiles, the upper and lower boundaries respectively indicate the 75th and 25 th percentiles, the lines in the boxes indicate the median values, and the cross symbols indicate the mean values), (g)-(i) high-resolution mass spectra of the three OA factors colored by six ion families at $m / z<120$, and ('g')-(i') the unit resolution mass spectra at $m / z>120$ for each OA factor.

were an important source of aerosol to the southern TPH (Engling et al., 2011; Xia et al., 2011; Putero et al., 2014; Cong et al., 2015). The $\mathrm{O} / \mathrm{C}$ ratio $(0.85)$ of $\mathrm{BBOA}$ in this study was quite a bit higher than BBOA factors identified at other urban/rural sites in previous studies (Aiken et al., 2009; Huang et al., 2011; Mohr et al., 2012; Sun et al., 2016; Xu et al., 2016), suggesting its long-range transport feature. This aged BBOA feature was similar with those obtained at other remote sites worldwide, such as a remote forest site in Finland (Raatikainen et al., 2010), a remote background site in Greece (Bougiatioti et al., 2014), and a national air quality background sites in southern China (Zhu et al., 2016), where OA were generally highly oxidized.

\subsubsection{NOA}

Besides the two highest signals at $m / z 43.99\left(\mathrm{CO}_{2}^{+}\right)$and $27.995\left(\mathrm{CO}^{+}\right)$which together contributed half of the total NOA signal due to the highly aged OA nature at QOMS, the NOA MS was also characterized by some nitrogencontaining fragments, such as $m / z 27.011\left(\mathrm{CHN}^{+}\right), 41.027$ $\left(\mathrm{C}_{2} \mathrm{H}_{3} \mathrm{~N}^{+}\right)$, and $43.006\left(\mathrm{CHON}^{+}\right)$. In total, these three fragments were thought to comprise nearly half of the nitrogen- 

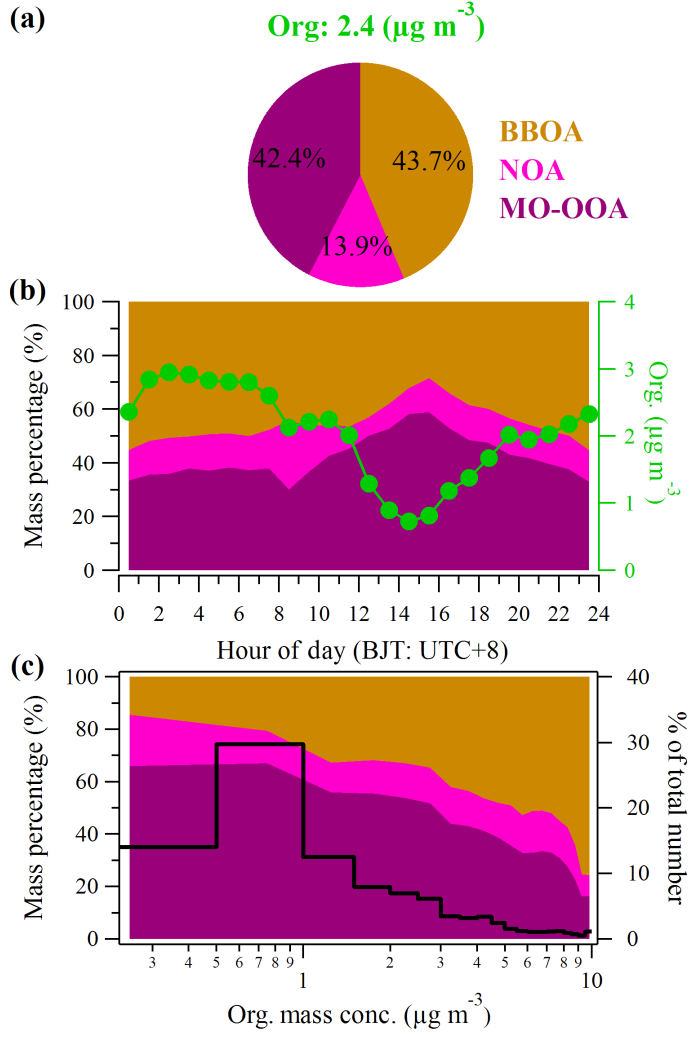

Figure 8. (a) The average mass concentration of OA and mass contributions of three OA factors to total OA; (b) the diurnal variations of mass contributions of three OA factors to total OA and the total OA mass concentration; and (c) the average mass contributions of three OA factors as a function of total OA mass concentrations. The black solid line in (c) shows the percentage of the data number in each OA mass bin to the total data number.

containing signals in the NOA factor and finally contributed $5 \%$ of the total NOA signal. The average $\mathrm{O} / \mathrm{C}$ ratio of NOA for the entire campaign was 1.10 with the highest $\mathrm{N} / \mathrm{C}$ ratio (0.068) among the three $\mathrm{OA}$ components. This high N / C ratio at QOMS was comparable with nitrogencontaining OA factors identified in previous studies, such as 0.06 in Mexico City (Aiken et al., 2009), 0.078 in Po Valley, Italy (Saarikoski et al., 2012), and 0.053 in New York (Sun et al., 2012). The time series of NOA showed tightly correlation $\left(R^{2}=0.62\right)$ with that of estimated organic nitrates, whereas relatively weak correlations with $\mathrm{PM}_{1}$ species and OA ions (Table S2). In addition, the $f_{60}$ value $(\sim 0.37 \%)$ was also slightly higher than the background $f_{60}(0.3 \%)$ of BB aerosols (Fig. 7h). These results together suggested that this oxygenated OA factor was likely a nitrogen-containing $\mathrm{OA}$ and might be related to the aged $\mathrm{BB}$ emissions, consistent with results from previous studies stating that large amounts of nitrogen-containing organic compounds were found from BB aerosols (Laskin et al., 2009; Gautam et al., 2016; Wang et al., 2017). Recently, Fleming et al. (2018) found dung burning, a very popular activity in Himalayas and India for residential cooking and heating, could emit much more nitrogen-containing OA than wood burning. Our filter samples during high BBOA period analyzed by Fourier Transform Ion Cyclotron Resonance Mass Spectrometry (FTICRMS) also found amount of ON molecular (in preparation). As shown in Figs. 7e and 8b, both the diurnal cycles of mass concentrations and fractions of NOA displayed a distinct increase in the morning, similar to the diurnal patterns of chloride, element ratios of $\mathrm{H} / \mathrm{C}$ and $\mathrm{N} / \mathrm{C}$, and the estimated organic nitrates. This diurnal feature of NOA at QOMS was quite consistent with NOA factors identified in Po Valley, Italy (Saarikoski et al., 2012) and in Mexico City (Aiken et al., 2009), or less-oxidized oxygenated OA (LO-OOA) in the southeastern USA (Xu et al., 2015) where have active BB emissions. NOA contributed $\sim 14 \%$ of the total OA mass on average, with an average mass concentration of $0.34 \mu \mathrm{g} \mathrm{m}^{-3}$ for the entire study (Fig. 8a).

\subsubsection{MO-OOA}

An obvious more oxygenated OA factor was also identified in this study according to its significant high signal at $m / z 44$ $(\sim 25 \%)$ and the high average $\mathrm{O} / \mathrm{C}$ ratio of 1.34 (Fig. 7i). The time series of MO-OOA correlated closely $\left(R^{2}=0.7\right)$ with sulfate and nitrate (Fig. 7c and Table S2). Moreover, the mass spectrum of MO-OOA in this study tightly resembled more aged and low-volatility oxygenated OA (LV-OOA) observed using AMS instruments at various sites worldwide (Fig. S9), e.g., an $R^{2}$ of 0.89 and 0.97 to those in Lanzhou, China (Xu et al., 2014; X. Zhang et al., 2017), 0.96 to that in Paris, France (Crippa et al., 2013), 0.95 to that in Barcelona, Spain (Mohr et al., 2012), in addition to 0.70 and 0.71 to the standard LV-OOA mass spectrums obtained from abundant AMS data sets by Ng et al. (2011a) and Crippa et al. (2014). The diurnal variation of MO-OOA was mainly driven by the dynamics of the PBL height, with high concentrations during the nighttime yet relatively low concentrations during daytime (Fig. 7f). This pattern was quite different to those observed in previous studies in that LV-OOA generally showed elevated concentrations during the afternoon in accordance with strong photochemical activities, suggesting that SOA at QOMS were mainly oxidized and aged during long-range transport. On average, MO-OOA contributed $42.4 \%$ of the total OA mass, with an average mass concentration of $1.02 \mu \mathrm{g} \mathrm{m}^{-3}$ for the entire study (Fig. 8a). As shown in Figs. $2 \mathrm{f}$ and $8 \mathrm{c}$, MO-OOA also displayed enhanced mass contributions during the clear periods, especially for the period after 2 May when the average mass fraction of MO-OOA increased to $\sim 68 \%$ of the total OA mass. 


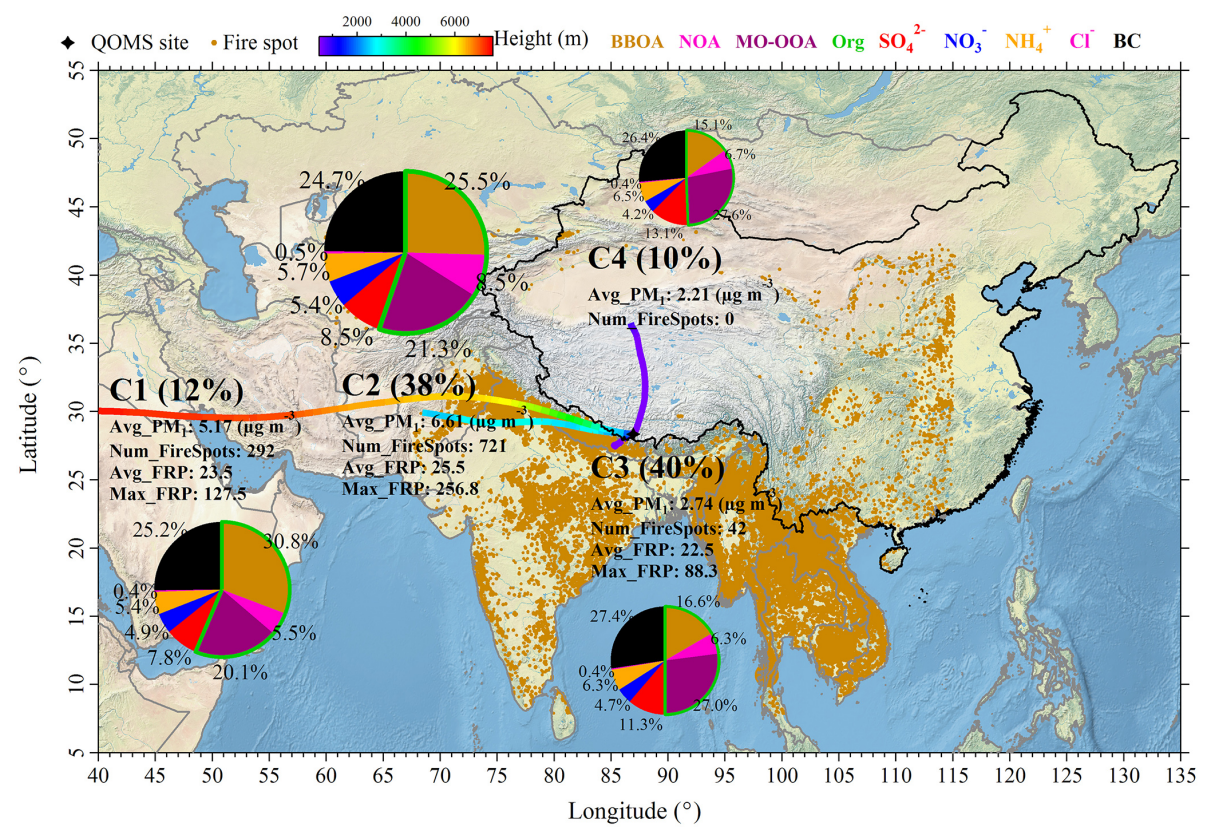

Figure 9. The average back trajectory clusters during the entire study and the corresponding mass contributions of $\mathrm{PM}_{1} \mathrm{species}$ and $\mathrm{OA}$ factors to the total $\mathrm{PM}_{1}$ mass. The areas of each pie chart are scaled by the corresponding average $\mathrm{PM}_{1}$ mass concentrations. The average $\mathrm{PM}_{1}$ mass concentrations, number of fire hotspots as well as the average and maximum fire radiative powers (FRP) belonging to each of the clusters during the entire measurement period are also given.

\subsection{Impact of BB emissions on aerosol characteristics}

\subsubsection{Sources of BB aerosols}

In order to understand the transport pathways and the potential source areas of aerosol, three-day back trajectories of air mass were calculated at an ending height of $500 \mathrm{~m}$ a.g.l. every $6 \mathrm{~h}$ at the QOMS from 12 April to 12 May 2016. A fourcluster solution and the wildfire hotspots around the QOMS during the entire measurement period are presented in Fig. 9. Cluster 1 and 2 (C1 and $\mathrm{C} 2$ ), which originated from the west of the QOMS and passed over many hotspot areas (e.g., IndoGangetic Plain and Nepal), represented two polluted clusters. On the contrary, $\mathrm{C} 3$ and $\mathrm{C} 4$, which accounted for half of the total back trajectories, were identified as clear clusters. C3 traveled a short distance from the southwest of the QOMS, whereas C4 was from the north of the QOMS and passed over the inland of the TPH. The average $\mathrm{PM}_{1}$ mass concentrations for $\mathrm{C} 1$ and $\mathrm{C} 2$ were 5.17 and $6.61 \mu \mathrm{g} \mathrm{m}^{-3}$, respectively, which were two to three times higher than those for the two clear clusters $\left(2.74\right.$ and $2.21 \mu \mathrm{g} \mathrm{m}^{-3}$ ). The mass contributions of $\mathrm{OA}$ and $\mathrm{BBOA}$ during $\mathrm{C} 1$ and $\mathrm{C} 2$ were up to more than 55 and $25 \%$ of the total $\mathrm{PM}_{1}$ mass on average, whereas weak contributions were found for the clear clusters (C3 and C4), indicating the significant impacts of BB emissions from South Asia on aerosol loadings at QOMS.

\subsubsection{Comparison of aerosol characteristics and air mass origins during different episodes}

As shown in Fig. 2, the mass concentrations and compositions of $\mathrm{PM}_{1}$ varied dynamically during the entire sampling period. Two polluted periods (PP1 and PP2) and two clear periods (CP1 and CP2) were identified. The comparisons of average mass concentrations and other indicators for the four different episodes were presented in box plots in Fig. 10, whereas the corresponding back trajectories of air masses and MODIS fire hotspots belong to each episode period were given in Fig. 11, respectively.

During the two polluted periods, $\mathrm{PM}_{1}$ mass concentrations were much higher than those in clear periods (8.06 and $7.87 \mu \mathrm{g} \mathrm{m}^{-3}$ for PP1 and PP2 vs. 2.76 and $1.82 \mu \mathrm{g} \mathrm{m}^{-3}$ for CP1 and CP2; similarly hereinafter), with higher contributions from OA (60.1 and $57.5 \%$ vs. 48.1 and $43.9 \%)$ and BBOA (38.3 and $36.6 \%$ vs. 14.3 and $7.5 \%$ ) (Figs. 10 and 11). In addition, $f_{60}$ were also higher during polluted periods than those for clear periods $(0.34$ and $0.34 \%$ vs. 0.26 and $0.22 \%$ on average) (Fig. 10). Air masses during PP1 and PP2 generally originated from long-range transport to the west of the QOMS, which would pass through intense wildfires areas in South Asia (e.g., Indo-Gangetic Plain and Nepal where high AOD values are shown in Fig. 1d and active fire hotspots are displayed in Figs. 9 and 11). The number of fire hotspots around the air mass trajectories during PP2 was more than three times higher than during other periods. 

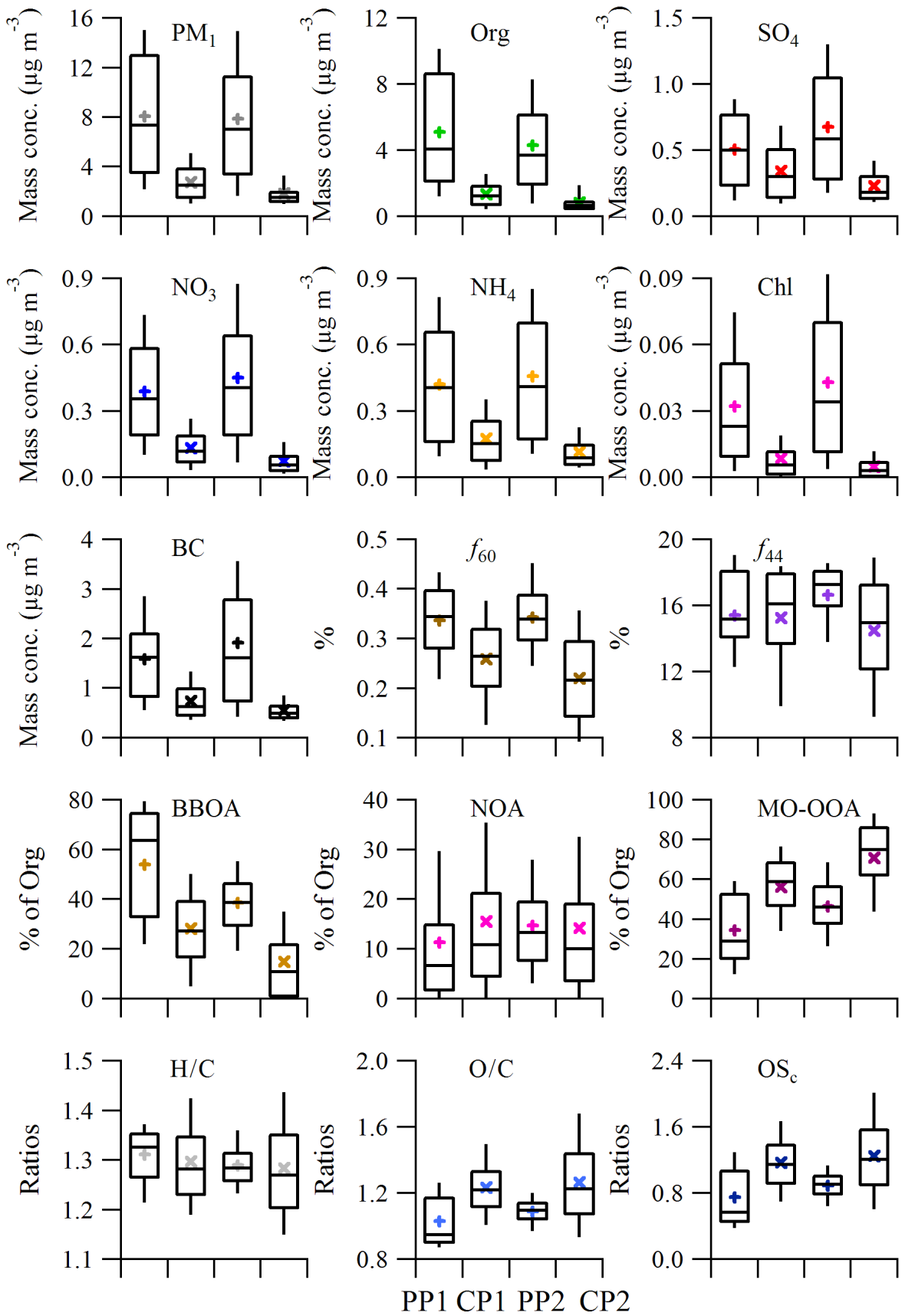

Figure 10. Box plots of mass concentrations of total $\mathrm{PM}_{1}$ and its species, $f_{60}$ and $f_{44}$ values, mass contribution of three OA components to organics, element ratios $(\mathrm{H} / \mathrm{C}$ and $\mathrm{O} / \mathrm{C})$, and carbon oxidation states $\left(\mathrm{OS}_{\mathrm{c}}\right)$ among the four polluted and clear periods. The whiskers indicate the 90th and 10th percentiles, the upper and lower boundaries of boxes indicate the 75 th and 25 th percentiles, the lines in the boxes indicate the median values, and the markers indicate the mean values.

Although the hotspot number around the air mass trajectories during PP1 was not as abundant as that during PP2 and even slightly lower than that during CP1, it was only collected within three days for PP1 whereas 8-10 days for the other periods. Hence, the BB activities were also more frequent and intense during the short PP1 and finally resulted in the highest average $\mathrm{PM}_{1}$ mass concentration among these periods. Back trajectories in $\mathrm{CP} 1$ also originated from the west of QOMS and passed over northern India and Nepal; however, both the intensity of the number of fire hotspots (1089 hotspots in $\sim$ eight days) and average FRP (19.6) were obvious lower than that in PP2. CP2 was the most clear period, during which the average $\mathrm{PM}_{1}$ mass concentration was more than four times lower than those in polluted periods. 

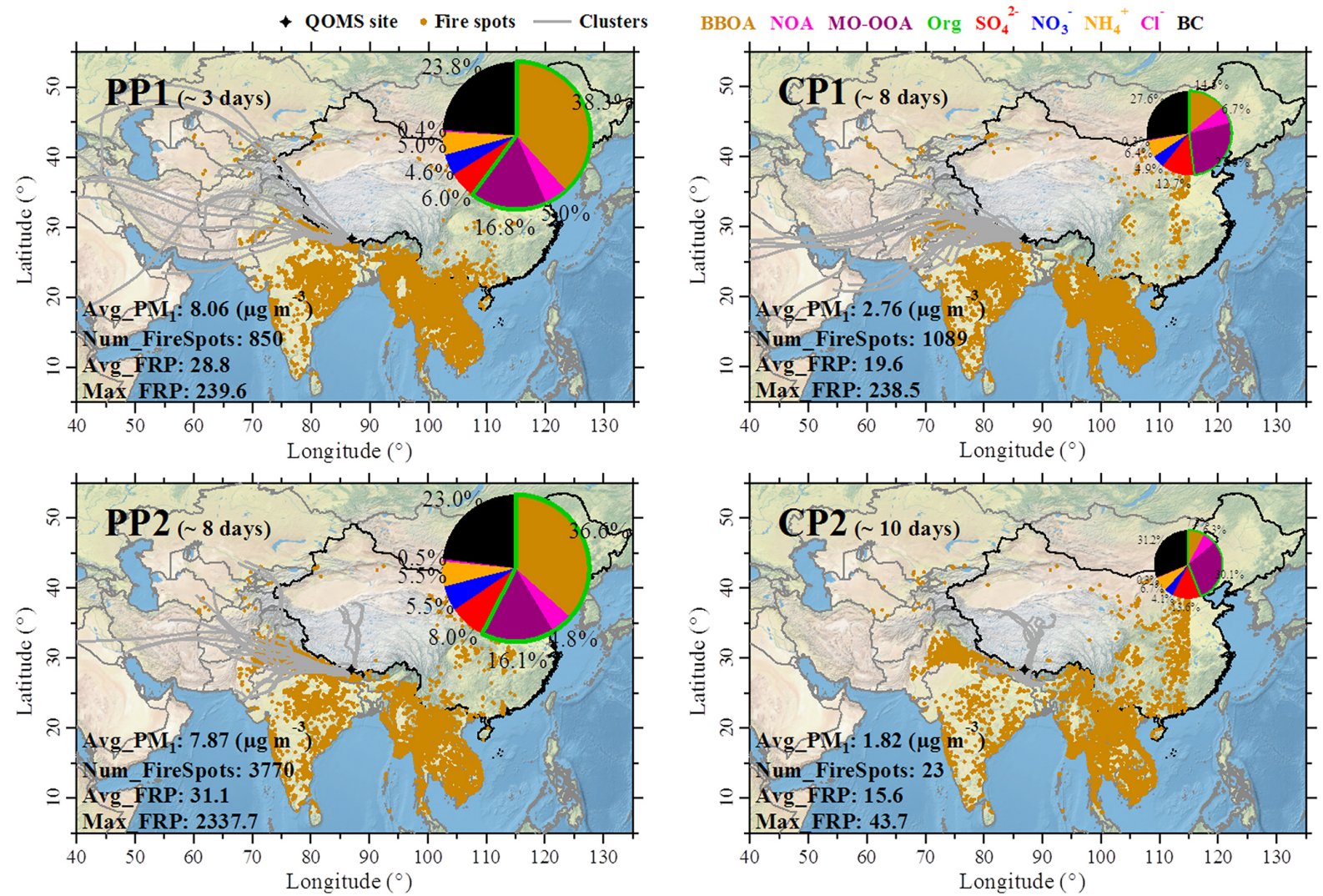

Figure 11. The $72 \mathrm{~h}$ back trajectories (grey solid lines) calculated every $6 \mathrm{~h}$ for the different episodes. Pie charts show the average mass contributions of $\mathrm{PM}_{1}$ species and $\mathrm{OA}$ factors to the total $\mathrm{PM}_{1}$ mass for each of the episodes (scaled by the corresponding average $\mathrm{PM}_{1}$ mass concentrations). The average $\mathrm{PM}_{1}$ mass concentrations, number of fire hotspots as well as the average and maximum fire radiative powers (FRP) belonging to all trajectories for the different episodes are also given.

Back trajectories during $\mathrm{CP} 2$ period were from either the north of QOMS which passed over inland areas of the TPH or the south of QOMS with quite short distances and low WSs. These results together suggested the significant roles of air mass sources and $\mathrm{BB}$ emissions to aerosol characteristics at QOMS.

\subsubsection{Case study on the chemical evolution of BB emission aerosols}

In order to examine how atmospheric aging affects the aerosol chemistry characteristics at QOMS, the typical evolution process of a $\mathrm{BB}$ aerosol plume (referred as BB evolution case) was analyzed from 30 April at 15:00 LT when a fresh BB plume occurred to 1 May at 18:00 LT when the BB plume was highly aged after undergoing various atmospheric oxidation processes. The temporal variations of meteorological parameters, mass concentrations, and mass contributions of each $\mathrm{PM}_{1}$ species and $\mathrm{OA}$ components as well as other chemistry parameters before and during this $\mathrm{BB}$ evolution case were all shown in Fig. 12.

Before the BB evolution case, all the mass concentrations decreased slowly and synchronously from 00:00 to 10:00 LT on 30 April. This was consistent with the nearly stable trends of mass contributions and other chemistry parameters, indicating the relatively unified air mass sources and stable atmospheric conditions. After that, the wind circulation changed from thermally-driven down-slope winds (mostly southwest) to weak up-slope winds (northeast). In this period, BBOA and $f_{60}$ values kept relatively stable in contrast to other species likely due to the weakness of air dilution and local sources. All the species reached their minimum at around 15:00 LT due to the lift of PBL.

The BB evolution case in this study was further divided into three different situations (as marked with arrows in Figs. 12 and 13), including the arrival of the fresh BBOA plume (from 15:00 to 24:00 LT on 30 April), followed by aqueous-phase oxidation at nighttime (from 02:30 to 07:10 LT on 1 May), and photochemical oxidation during the daytime (from 10:00 to 18:00 LT on 1 May). All the mass concentrations began to increase from 15:00 LT and finally reached maximum $\mathrm{PM}_{1}$ mass loading of $18.4 \mu \mathrm{g} \mathrm{m}^{-3}$ at 24:00 LT, which was about four times higher than the average $\mathrm{PM}_{1}$ mass during the entire campaign. Thus continuous increase was mainly dominated by the dramatic increase 


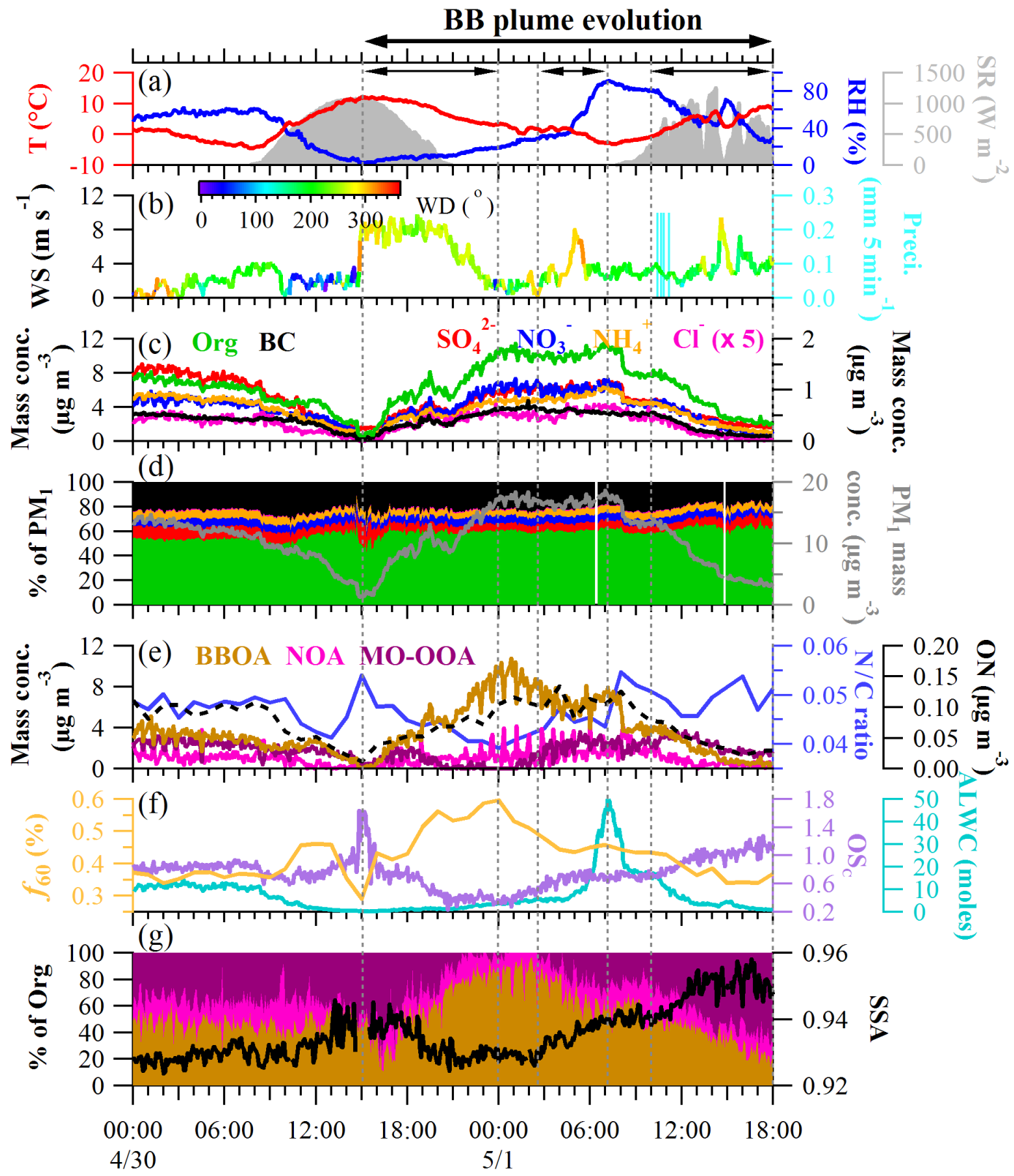

Date \& time (BJT: UTC+8)

Figure 12. The temporal variations of meteorological parameters, mass concentrations, and mass contributions of each $\mathrm{PM}_{1} \mathrm{species}_{\mathrm{ind}} \mathrm{OA}$ components as well as the $\mathrm{N} / \mathrm{C}$ ratio, $f_{60}$ values, carbon oxidation states $\left(\mathrm{OS}_{\mathrm{c}}\right)$, aerosol liquid water content (ALWC), and single scattering albedo (SSA) for the case study period from 30 April at 00:00 LT to 1 May at 18:00 LT.

of BBOA, which reached up to $10.8 \mu \mathrm{g} \mathrm{m}^{-3}$ and contributed $88 \%$ of the total $\mathrm{OA}$ mass and $50 \%$ of the total $\mathrm{PM}_{1}$ at 24:00 LT (Fig. 13a), suggesting a distinct presence of BB emissions during this period. In contrast, the total OA mass was comprised of $78 \%$ of MO-OOA and $12 \%$ of BBOA at 15:00 LT. Similar continuous increasing trends could also be found for the mass concentration of calculated organic nitrate in this stage. In addition, nine aerosol chemistry parameters were presented as a function of BBOA mass con- centrations during this period (Fig. 13b). The mass contributions of $\mathrm{OA}$ to $\mathrm{PM}_{1}\left(f_{\mathrm{Org}}\right)$ and $\mathrm{BBOA}$ to total $\mathrm{OA}\left(f_{\mathrm{BBOA}}\right)$, $f_{60}$, and $\mathrm{H} / \mathrm{C}$ ratio were all increased with the increasing BBOA mass, whereas the mass contribution of MO-OOA to total OA $\left(f_{\mathrm{MO}-\mathrm{OOA}}\right), \mathrm{O} / \mathrm{C}$ ratio, carbon oxidation state $\left(\mathrm{OS}_{\mathrm{c}}=2 \times \mathrm{O} / \mathrm{C}-\mathrm{H} / \mathrm{C}\right)$ of $\mathrm{OA}$, and aerosol single scattering albedo (SSA) were decreased, obviously indicating the fresh nature of this BB plume. The significant impacts of the fresh BB plume during this period were mainly associated 


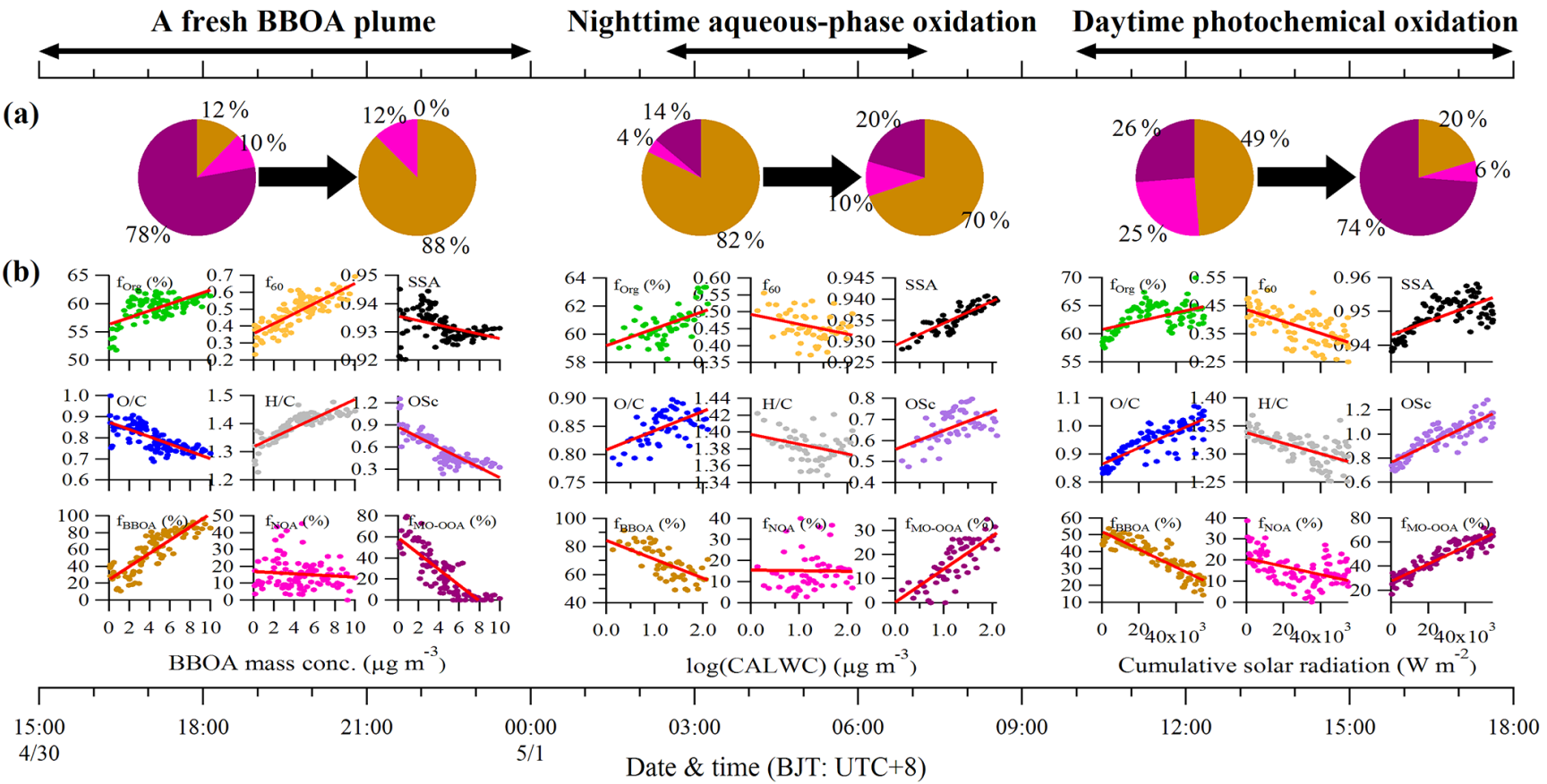

Figure 13. Case study of chemical evolution of BB plume from 30 April at 15:00 LT to 1 May at 18:00 LT. The periods marked with arrows are three distinct evolution processes. Pie charts in (a) are the mass contributions of three OA factors to total OA at the beginning and end of each process, respectively. The scatter plots in (b) are the aerosol chemistry parameters as a function of BBOA mass concentration, logarithmic values of cumulative aerosol liquid water content (CALWC), and cumulative solar radiation for the corresponding process.

with the unique wind circulation and the long-range transport of air masses. As displayed in Fig. 12b, the wind circulation changed from the weak up-slope winds to the strong down-slope glacier winds on 30 April at 15:00 LT, with a WS increase from $\sim 2$ to $8 \mathrm{~m} \mathrm{~s}^{-1}$. Meanwhile, the back trajectories during this period also showed that the air masses passed over northern India and Nepal, where active wildfires occurred. The air masses then accumulated and uplifted to the Himalayas and finally moved downward to the QOMS with the strong glacier winds.

A distinct aqueous-phase oxidation process was found in the nighttime from 02:30 to 07:10 LT on 1 May. Although the total $\mathrm{PM}_{1}$ and its species showed nearly stable mass concentrations during this period, the BBOA mass decreased gradually (from 82 to $70 \%$ ) whereas MO-OOA increased constantly (from 14 to $20 \%$ ) with the significant increase of RH (up to 91 \}) and aerosol liquid water content (ALWC) (Fig. 12). The scatter plots of the aerosol chemistry parameters vs. the logarithmic values of cumulative ALWC, which could be used for the aqueous-phase oxidation during transport, also showed apparent increase trends for $f_{\mathrm{MO}-\mathrm{OOA}}, \mathrm{O} / \mathrm{C}$ ratio, $\mathrm{OS}_{\mathrm{c}}$, and SSA that generally indicated the aerosol aging extent. All of these together suggested a distinct aqueous-phase oxidation of BBOA in the nighttime.

From sunrise, all mass concentrations decreased gradually, which was mainly related to the increasing PBL height and clear air mass dilution. The back trajectories indicated that air masses during this period firstly moved inland north of QOMS where rare wildfires took place. Moreover, the BB plume further underwent strong photochemical oxidation during the daytime due to the strong solar radiation. MO-OOA only contributed $26 \%$ of the total OA mass at 10:00 LT, but it could increase to $74 \%$ at 18:00 LT after longtime photochemical oxidation. In contrast, BBOA mass contribution decreased from 49 to $20 \%$. The cumulative solar radiation, which denoted the total amount of solar radiation that the plumes were exposed to during transport, could be used as an indicator of the extent of photochemical aging in the daytime (Zhou et al., 2017). Clear increasing trends were found for $f_{\mathrm{MO}-\mathrm{OOA}}, \mathrm{O} / \mathrm{C}$ ratio, $\mathrm{OS}_{\mathrm{c}}$, and SSA values with increasing cumulative solar radiation, whereas decreasing trends in $f_{\mathrm{BBOA}}, f_{\mathrm{NOA}}, \mathrm{H} / \mathrm{C}$ ratio, and $f_{60}$ values were observed, suggesting a possible oxidation mechanism that oxidized the relatively fresh BBOA and NOA to aged MO-OOA during the daytime. Another interesting phenomenon was the continuous increase of SSA during both the aqueous-phase and photochemical oxidation periods on 1 May (Figs. 12e and 13b), indicating the potential influence of atmospheric aging to aerosol optical property at QOMS. 


\section{Conclusions}

A comprehensive characterization of submicron aerosol chemical compositions and sources was investigated at the QOMS during the pre-monsoon season in 2016. The average mass concentration of $\mathrm{PM}_{1}\left(\mathrm{NR}-\mathrm{PM}_{1}+\mathrm{BC}\right)$ was $4.44( \pm 4.54) \mu \mathrm{g} \mathrm{m}^{-3}$ for the entire study, which was much lower than those observed in various sites in China. OA was the dominant $\mathrm{PM}_{1}$ species (accounted for $54.3 \%$ of the total mass on average) and its contributions increased with the increase $\mathrm{PM}_{1}$ mass loading. The average size distributions of all $\mathrm{PM}_{1}$ species displayed an overlapping and narrow accumulation mode at $\sim 500 \mathrm{~nm}$, indicating internally well-mixed and aged aerosol particles at the QOMS. All species presented similar diurnal cycles, with lower concentrations in the daytime and higher concentrations at nighttime, mainly attributed to the dynamic variations of PBL height. Three OA factors were identified by PMF analysis on the high-resolution OA mass spectrum, including a relatively fresh BB-related OA (BBOA), a nitrogen-containing $\mathrm{OA}$ (NOA) and a more-oxidized oxygenated OA (MOOOA). BBOA and MO-OOA could respectively account for 43.7 and $42.4 \%$ of OA mass on average; however, their contributions to OA showed completely opposite trends with the increase of OA mass. A continuously increasing trend could be found for BBOA with increasing OA, suggesting the key role of BBOA during polluted periods when frequent and intense wildfires were observed in South Asia. The significant impact of BB emissions on aerosol characteristics at QOMS have also been illustrated for different air mass origins and periods. Elevated $\mathrm{PM}_{1}$ mass concentrations and high contributions of BBOA were found for both polluted clusters and polluted periods. A case study of typical evolution process of $\mathrm{BB}$ aerosol plume was investigated in detail to illustrate the chemical evolution of aerosol characteristics at the QOMS. The fresh BB plume occurred in the afternoon on 30 April and finally resulted in highly $\mathrm{PM}_{1}$ mass loading of $18.4 \mu \mathrm{g} \mathrm{m}^{-3}$, which was about four times higher than the average $\mathrm{PM}_{1}$ mass during the entire campaign. Obvious aqueous-phase oxidation and photochemical oxidation processes were analyzed during nighttime and daytime on 1 May, both suggesting the mechanism that oxidized fresh BBOA to aged MO-OOA. The continuous increase of SSA during the two oxidation periods suggested the potential influence of atmospheric aging on aerosol optical property at QOMS.

Data availability. The processed AMS data and meteorological data in this study are available upon request from the corresponding author.
Supplement. The supplement related to this article is available online at: https://doi.org/10.5194/acp-18-4617-2018-supplement.

Competing interests. The authors declare that they have no conflict of interest.

Special issue statement. This article is part of the special issue "Pan-Eurasian Experiment (PEEX)". It does not belong to a conference.

Acknowledgements. This research was supported by grants from the National Natural Science Foundation of China (41771079, 41421061), the Key Laboratory of Cryospheric Sciences Scientific Research Foundation (SKLCS-ZZ-2017-01), and the Chinese Academy of Sciences Hundred Talents Program. The authors thank their colleagues for continuing support and discussion, and thank the NOAA Air Resources Laboratory, NASA MODIS, and FIRMS teams for providing the HYSPLIT trajectory model, AOD, and fire hotspots datasets.

Edited by: Veli-Matti Kerminen

Reviewed by: three anonymous referees

\section{References}

Aiken, A. C., DeCarlo, P. F., Kroll, J. H., Worsnop, D. R., Huffman, J. A., Docherty, K. S., Ulbrich, I. M., Mohr, C., Kimmel, J. R., Sueper, D., Sun, Y., Zhang, Q., Trimborn, A., Northway, M., Ziemann, P. J., Canagaratna, M. R., Onasch, T. B., Alfarra, M. R., Prevot, A. S. H., Dommen, J., Duplissy, J., Metzger, A., Baltensperger, U., and Jimenez, J. L.: $\mathrm{O} / \mathrm{C}$ and $\mathrm{OM} / \mathrm{OC}$ ratios of primary, secondary, and ambient organic aerosols with high-resolution time-of-flight aerosol mass spectrometry, Environ. Sci. Technol., 42, 4478-4485, https://doi.org/10.1021/es703009q, 2008.

Aiken, A. C., Salcedo, D., Cubison, M. J., Huffman, J. A., DeCarlo, P. F., Ulbrich, I. M., Docherty, K. S., Sueper, D., Kimmel, J. R., Worsnop, D. R., Trimborn, A., Northway, M., Stone, E. A., Schauer, J. J., Volkamer, R. M., Fortner, E., de Foy, B., Wang, J., Laskin, A., Shutthanandan, V., Zheng, J., Zhang, R., Gaffney, J., Marley, N. A., Paredes-Miranda, G., Arnott, W. P., Molina, L. T., Sosa, G., and Jimenez, J. L.: Mexico City aerosol analysis during MILAGRO using high resolution aerosol mass spectrometry at the urban supersite (T0) - Part 1: Fine particle composition and organic source apportionment, Atmos. Chem. Phys., 9, 6633-6653, https://doi.org/10.5194/acp-9-6633-2009, 2009.

Alfarra, M. R., Coe, H., Allan, J. D., Bower, K. N., Boudries, H., Canagaratna, M. R., Jimenez, J. L., Jayne, J. T., Garforth, A. A., Li, S.-M., and Worsnop, D. R.: Characterization of urban and rural organic particulate in the Lower Fraser Valley using two Aerodyne Aerosol Mass Spectrometers, Atmos. Environ., 38, 5745-5758, https://doi.org/10.1016/j.atmosenv.2004.01.054, 2004.

Alfarra, M. R., Prevot, A. S. H., Szidat, S., Sandradewi, J., Weimer, S., Lanz, V. A., Schreiber, D., Mohr, M., and Baltensperger, 
U.: Identification of the Mass Spectral Signature of Organic Aerosols from Wood Burning Emissions, Environ. Sci. Technol., 41, 5770-5777, https://doi.org/10.1021/es062289b, 2007.

Bonasoni, P., Laj, P., Marinoni, A., Sprenger, M., Angelini, F., Arduini, J., Bonafè, U., Calzolari, F., Colombo, T., Decesari, S., Di Biagio, C., di Sarra, A. G., Evangelisti, F., Duchi, R., Facchini, M. C., Fuzzi, S., Gobbi, G. P., Maione, M., Panday, A., Roccato, F., Sellegri, K., Venzac, H., Verza, G. P., Villani, P., Vuillermoz, E., and Cristofanelli, P.: Atmospheric Brown Clouds in the Himalayas: first two years of continuous observations at the Nepal Climate Observatory-Pyramid (5079 m), Atmos. Chem. Phys., 10, 7515-7531, https://doi.org/10.5194/acp10-7515-2010, 2010.

Bond, T. C., Streets, D. G., Yarber, K. F., Nelson, S. M., Woo, J.-H., and Klimont, Z.: A technology-based global inventory of black and organic carbon emissions from combustion, J. Geophys. Res., 109, D14203, https://doi.org/10.1029/2003jd003697, 2004.

Bougiatioti, A., Stavroulas, I., Kostenidou, E., Zarmpas, P., Theodosi, C., Kouvarakis, G., Canonaco, F., Prévôt, A. S. H., Nenes, A., Pandis, S. N., and Mihalopoulos, N.: Processing of biomass-burning aerosol in the eastern Mediterranean during summertime, Atmos. Chem. Phys., 14, 4793-4807, https://doi.org/10.5194/acp-14-4793-2014, 2014.

Canagaratna, M. R., Jayne, J. T., Jimenez, J. L., Allan, J. D., Alfarra, M. R., Zhang, Q., Onasch, T. B., Drewnick, F., Coe, H., Middlebrook, A., Delia, A., Williams, L. R., Trimborn, A. M., Northway, M. J., DeCarlo, P. F., Kolb, C. E., Davidovits, P., and Worsnop, D. R.: Chemical and microphysical characterization of ambient aerosols with the aerodyne aerosol mass spectrometer, Mass Spectrom. Rev., 26, 185-222, https://doi.org/10.1002/mas.20115, 2007.

Canagaratna, M. R., Jimenez, J. L., Kroll, J. H., Chen, Q., Kessler, S. H., Massoli, P., Hildebrandt Ruiz, L., Fortner, E., Williams, L. R., Wilson, K. R., Surratt, J. D., Donahue, N. M., Jayne, J. T., and Worsnop, D. R.: Elemental ratio measurements of organic compounds using aerosol mass spectrometry: characterization, improved calibration, and implications, Atmos. Chem. Phys., 15, 253-272, https://doi.org/10.5194/acp-15-253-2015, 2015.

Cong, Z., Kang, S., Kawamura, K., Liu, B., Wan, X., Wang, Z., Gao, S., and Fu, P.: Carbonaceous aerosols on the south edge of the Tibetan Plateau: concentrations, seasonality and sources, Atmos. Chem. Phys., 15, 1573-1584, https://doi.org/10.5194/acp15-1573-2015, 2015.

Crippa, M., DeCarlo, P. F., Slowik, J. G., Mohr, C., Heringa, M. F., Chirico, R., Poulain, L., Freutel, F., Sciare, J., Cozic, J., Di Marco, C. F., Elsasser, M., Nicolas, J. B., Marchand, N., Abidi, E., Wiedensohler, A., Drewnick, F., Schneider, J., Borrmann, S., Nemitz, E., Zimmermann, R., Jaffrezo, J. L., Prévôt, A. S. H., and Baltensperger, U.: Wintertime aerosol chemical composition and source apportionment of the organic fraction in the metropolitan area of Paris, Atmos. Chem. Phys., 13, 961-981, https://doi.org/10.5194/acp-13-961-2013, 2013.

Crippa, M., Canonaco, F., Lanz, V. A., Äijälä, M., Allan, J. D., Carbone, S., Capes, G., Ceburnis, D., Dall'Osto, M., Day, D. A., DeCarlo, P. F., Ehn, M., Eriksson, A., Freney, E., Hildebrandt Ruiz, L., Hillamo, R., Jimenez, J. L., Junninen, H., KiendlerScharr, A., Kortelainen, A. M., Kulmala, M., Laaksonen, A., Mensah, A. A., Mohr, C., Nemitz, E., O’Dowd, C., Ovadnevaite,
J., Pandis, S. N., Petäjä, T., Poulain, L., Saarikoski, S., Sellegri, K., Swietlicki, E., Tiitta, P., Worsnop, D. R., Baltensperger, U., and Prévôt, A. S. H.: Organic aerosol components derived from 25 AMS data sets across Europe using a consistent ME-2 based source apportionment approach, Atmos. Chem. Phys., 14, 61596176, https://doi.org/10.5194/acp-14-6159-2014, 2014.

Cubison, M. J., Ortega, A. M., Hayes, P. L., Farmer, D. K., Day, D., Lechner, M. J., Brune, W. H., Apel, E., Diskin, G. S., Fisher, J. A., Fuelberg, H. E., Hecobian, A., Knapp, D. J., Mikoviny, T., Riemer, D., Sachse, G. W., Sessions, W., Weber, R. J., Weinheimer, A. J., Wisthaler, A., and Jimenez, J. L.: Effects of aging on organic aerosol from open biomass burning smoke in aircraft and laboratory studies, Atmos. Chem. Phys., 11, 12049-12064, https://doi.org/10.5194/acp-11-12049-2011, 2011.

DeCarlo, P. F., Kimmel, J. R., Trimborn, A., Northway, M. J., Jayne, J. T., Aiken, A. C., Gonin, M., Fuhrer, K., Horvath, T., Docherty, K. S., Worsnop, D. R., and Jimenez, J. L.: Field-Deployable, High-Resolution, Time-ofFlight Aerosol Mass Spectrometer, Anal. Chem., 78, 8281-8289, https://doi.org/10.1021/ac061249n, 2006.

Decesari, S., Facchini, M. C., Carbone, C., Giulianelli, L., Rinaldi, M., Finessi, E., Fuzzi, S., Marinoni, A., Cristofanelli, P., Duchi, R., Bonasoni, P., Vuillermoz, E., Cozic, J., Jaffrezo, J. L., and Laj, P.: Chemical composition of $\mathrm{PM}_{10}$ and $\mathrm{PM}_{1}$ at the high-altitude Himalayan station Nepal Climate ObservatoryPyramid (NCO-P) (5079 ma.s.1.), Atmos. Chem. Phys., 10, 4583-4596, https://doi.org/10.5194/acp-10-4583-2010, 2010.

Draxler, R. R. and Rolph, G. D.: HYSPLIT (HYbrid Single-Particle Lagrangian Integrated Trajectory) model access via NOAA ARL READY website, NOAA Air Resources Laboratory, Silver Spring, MD, USA, http://www.arl.noaa.gov/ready/hysplit4.html, 2003.

Du, W., Sun, Y. L., Xu, Y. S., Jiang, Q., Wang, Q. Q., Yang, W., Wang, F., Bai, Z. P., Zhao, X. D., and Yang, Y. C.: Chemical characterization of submicron aerosol and particle growth events at a national background site (3295 ma.s.1.) on the Tibetan Plateau, Atmos. Chem. Phys., 15, 10811-10824, https://doi.org/10.5194/acp-15-10811-2015, 2015.

Duan, A. M. and Wu, G. X.: Role of the Tibetan Plateau thermal forcing in the summer climate patterns over subtropical Asia, Clim. Dynam., 24, 793-807, https://doi.org/10.1007/s00382004-0488-8, 2005.

Engling, G., Zhang, Y. N., Chan, C. Y., Sang, X. F., Lin, M., Ho, K. F., Li, Y. S., Lin, C. Y., and Lee, J. J.: Characterization and sources of aerosol particles over the southeastern Tibetan Plateau during the Southeast Asia biomass-burning season, Tellus B, 63, 117-128, https://doi.org/10.1111/j.1600-0889.2010.00512.x, 2011.

Fleming, L. T., Lin, P., Laskin, A., Laskin, J., Weltman, R., Edwards, R. D., Arora, N. K., Yadav, A., Meinardi, S., Blake, D. R., Pillarisetti, A., Smith, K. R., and Nizkorodov, S. A.: Molecular composition of particulate matter emissions from dung and brushwood burning household cookstoves in Haryana, India, Atmos. Chem. Phys., 18, 2461-2480, https://doi.org/10.5194/acp18-2461-2018, 2018.

Fröhlich, R., Cubison, M. J., Slowik, J. G., Bukowiecki, N., Canonaco, F., Croteau, P. L., Gysel, M., Henne, S., Herrmann, E., Jayne, J. T., Steinbacher, M., Worsnop, D. R., Baltensperger, U., and Prévôt, A. S. H.: Fourteen months of on-line measure- 
ments of the non-refractory submicron aerosol at the Jungfraujoch (3580 ma.s.1.) - chemical composition, origins and organic aerosol sources, Atmos. Chem. Phys., 15, 11373-11398, https://doi.org/10.5194/acp-15-11373-2015, 2015.

Gautam, S., Edwards, R., Yadav, A., Weltman, R., Pillarsetti, A., Arora, N. K., and Smith, K. R.: Probe-based measurements of moisture in dung fuel for emissions measurements, Energy Sustain. Dev., 35, 1-6, https://doi.org/10.1016/j.esd.2016.09.003, 2016.

Ge, X., Zhang, Q., Sun, Y., Ruehl, C. R., and Setyan, A.: Effect of aqueous-phase processing on aerosol chemistry and size distributions in Fresno, California, during wintertime, Environ. Chem., 9, 221-235, https://doi.org/10.1071/en11168, 2012.

Heald, C. L., Kroll, J. H., Jimenez, J. L., Docherty, K. S., DeCarlo, P. F., Aiken, A. C., Chen, Q., Martin, S. T., Farmer, D. K., and Artaxo, P.: A simplified description of the evolution of organic aerosol composition in the a tmosphere, Geophys. Res. Lett., 37, L08803, https://doi.org/10.1029/2010gl042737, 2010.

Hou, S., Qin, D., Zhang, D., Kang, S., Mayewski, P. A., and Wake, C. P.: A 154a high-resolution ammonium record from the Rongbuk Glacier, north slope of Mt. Qomolangma (Everest), Tibet-Himal region, Atmos. Environ., 37, 721-729, https://doi.org/10.1016/S1352-2310(02)00582-4, 2003.

Hu, W., Hu, M., Hu, W.-W., Niu, H., Zheng, J., Wu, Y., Chen, W., Chen, C., Li, L., Shao, M., Xie, S., and Zhang, Y.: Characterization of submicron aerosols influenced by biomass burning at a site in the Sichuan Basin, southwestern China, Atmos. Chem. Phys., 16, 13213-13230, https://doi.org/10.5194/acp-16-132132016, 2016.

Huang, X. F., He, L. Y., Hu, M., Canagaratna, M. R., Kroll, J. H., Ng, N. L., Zhang, Y. H., Lin, Y., Xue, L., Sun, T. L., Liu, X. G., Shao, M., Jayne, J. T., and Worsnop, D. R.: Characterization of submicron aerosols at a rural site in Pearl River Delta of China using an Aerodyne High-Resolution Aerosol Mass Spectrometer, Atmos. Chem. Phys., 11, 18651877, https://doi.org/10.5194/acp-11-1865-2011, 2011.

Huang, X. F., He, L. Y., Xue, L., Sun, T. L., Zeng, L. W., Gong, Z. H., Hu, M., and Zhu, T.: Highly time-resolved chemical characterization of atmospheric fine particles during 2010 Shanghai World Expo, Atmos. Chem. Phys., 12, 48974907, https://doi.org/10.5194/acp-12-4897-2012, 2012.

Jayne, J. T., Leard, D. C., Zhang, X. F., Davidovits, P., Smith, K. A., Kolb, C. E., and Worsnop, D. R.: Development of an aerosol mass spectrometer for size and composition analysis of submicron particles, Aerosol Sci. Tech., 33, 49-70, https://doi.org/10.1080/027868200410840, 2000.

Jimenez, J. L., Jayne, J. T., Shi, Q., Kolb, C. E., Worsnop, D. R., Yourshaw, I., Seinfeld, J. H., Flagan, R. C., Zhang, X., Smith, K. A., Morris, J. W., and Davidovits, P.: Ambient aerosol sampling using the Aerodyne Aerosol Mass Spectrometer, J. Geophys. Res., 108, 8425, https://doi.org/10.1029/2001jd001213, 2003.

Jimenez, J. L., Canagaratna, M. R., Donahue, N. M., Prevot, A. S., Zhang, Q., Kroll, J. H., DeCarlo, P. F., Allan, J. D., Coe, H., Ng, N. L., Aiken, A. C., Docherty, K. S., Ulbrich, I. M., Grieshop, A. P., Robinson, A. L., Duplissy, J., Smith, J. D., Wilson, K. R., Lanz, V. A., Hueglin, C., Sun, Y. L., Tian, J., Laaksonen, A., Raatikainen, T., Rautiainen, J., Vaattovaara, P., Ehn, M., Kulmala, M., Tomlinson, J. M., Collins, D. R., Cubison, M. J., Dunlea, E. J., Huffman, J. A., Onasch, T. B., Al- farra, M. R., Williams, P. I., Bower, K., Kondo, Y., Schneider, J., Drewnick, F., Borrmann, S., Weimer, S., Demerjian, K., Salcedo, D., Cottrell, L., Griffin, R., Takami, A., Miyoshi, T., Hatakeyama, S., Shimono, A., Sun, J. Y., Zhang, Y. M., Dzepina, K., Kimmel, J. R., Sueper, D., Jayne, J. T., Herndon, S. C., Trimborn, A. M., Williams, L. R., Wood, E. C., Middlebrook, A. M., Kolb, C. E., Baltensperger, U., and Worsnop, D. R.: Evolution of organic aerosols in the atmosphere, Science, 326, 1525-1529, https://doi.org/10.1126/science.1180353, 2009.

Kang, S., Xu, Y., You, Q., Flügel, W.-A., Pepin, N., and Yao, T.: Review of climate and cryospheric change in the Tibetan Plateau, Environ. Res. Lett., 5, 015101, https://doi.org/10.1088/17489326/5/1/015101, 2010.

Laskin, A., Smith, J. S., and Laskin, J.: Molecular Characterization of Nitrogen-Containing Organic Compounds in Biomass Burning Aerosols Using High-Resolution Mass Spectrometry, Environ. Sci. Technol., 43, 3764-3771, https://doi.org/10.1021/es803456n, 2009.

Lau, K. M., Kim, M. K., and Kim, K. M.: Asian summer monsoon anomalies induced by aerosol direct forcing: the role of the Tibetan Plateau, Clim. Dynam., 26, 855-864, https://doi.org/10.1007/s00382-006-0114-z, 2006.

Lau, K. M., Tsay, S. C., Hsu, C., Chin, M., Ramanathan, V., Wu, G. X., Li, Z., Sikka, R., Holben, B., Lu, D., Chen, H., Tartari, G., Koudelova, P., Ma, Y., Huang, J., Taniguchi, K., and Zhang, R.: The Joint Aerosol-Monsoon Experiment: A New Challenge for Monsoon Climate Research, B. Am. Meteorol. Soc., 89, 369383, https://doi.org/10.1175/bams-89-3-369, 2008.

Li, C., Bosch, C., Kang, S., Andersson, A., Chen, P., Zhang, Q., Cong, Z., Chen, B., Qin, D., and Gustafsson, O.: Sources of black carbon to the Himalayan-Tibetan Plateau glaciers, Nat. Commun., 7, 12574, https://doi.org/10.1038/ncomms12574, 2016.

Li, Y. J., Sun, Y., Zhang, Q., Li, X., Li, M., Zhou, Z., and Chan, C. K.: Real-time chemical characterization of atmospheric particulate matter in China: A review, Atmos. Environ., 158, 270-304, https://doi.org/10.1016/j.atmosenv.2017.02.027, 2017.

Liu, B., Cong, Z., Wang, Y., Xin, J., Wan, X., Pan, Y., Liu, Z., Wang, Y., Zhang, G., Wang, Z., Wang, Y., and Kang, S.: Background aerosol over the Himalayas and Tibetan Plateau: observed characteristics of aerosol mass loading, Atmos. Chem. Phys., 17, 449-463, https://doi.org/10.5194/acp-17-449-2017, 2017.

Liu, Z., Liu, D., Huang, J., Vaughan, M., Uno, I., Sugimoto, N., Kittaka, C., Trepte, C., Wang, Z., Hostetler, C., and Winker, D.: Airborne dust distributions over the Tibetan Plateau and surrounding areas derived from the first year of CALIPSO lidar observations, Atmos. Chem. Phys., 8, 5045-5060, https://doi.org/10.5194/acp8-5045-2008, 2008.

Ma, Y., Kang, S., Zhu, L., Xu, B., Tian, L., and Yao, T. ROOF OF THE WORLD: Tibetan Observation and Research Platform, B. Am. Meteorol. Soc., 89, 1487-1492, https://doi.org/10.1175/2008bams2545.1, 2008.

Marcq, S., Laj, P., Roger, J. C., Villani, P., Sellegri, K., Bonasoni, P., Marinoni, A., Cristofanelli, P., Verza, G. P., and Bergin, M.: Aerosol optical properties and radiative forcing in the high Himalaya based on measurements at the Nepal Climate Observatory-Pyramid site (5079 m a.s.1.), Atmos. Chem. Phys., 10, 5859-5872, https://doi.org/10.5194/acp-105859-2010, 2010. 
Marinoni, A., Cristofanelli, P., Laj, P., Duchi, R., Putero, D., Calzolari, F., Landi, T. C., Vuillermoz, E., Maione, M., and Bonasoni, P.: High black carbon and ozone concentrations during pollution transport in the Himalayas: Five years of continuous observations at NCO-P global GAW station, J. Environ. Sci., 25, 1618-1625, https://doi.org/10.1016/S1001-0742(12)60242-3, 2013.

Mohr, C., DeCarlo, P. F., Heringa, M. F., Chirico, R., Slowik, J. G., Richter, R., Reche, C., Alastuey, A., Querol, X., Seco, R., Peñuelas, J., Jiménez, J. L., Crippa, M., Zimmermann, R., Baltensperger, U., and Prévôt, A. S. H.: Identification and quantification of organic aerosol from cooking and other sources in Barcelona using aerosol mass spectrometer data, Atmos. Chem. Phys., 12, 1649-1665, https://doi.org/10.5194/acp-121649-2012, 2012.

Ng, N. L., Canagaratna, M., Jimenez, J., Zhang, Q., Ulbrich, I., and Worsnop, D.: Real-time methods for estimating organic component mass concentrations from aerosol mass spectrometer data, Environ. Sci. Technol., 45, 910-916, https://doi.org/10.1021/es102951k, 2011a.

Ng, N. L., Canagaratna, M. R., Jimenez, J. L., Chhabra, P. S., Seinfeld, J. H., and Worsnop, D. R.: Changes in organic aerosol composition with aging inferred from aerosol mass spectra, Atmos. Chem. Phys., 11, 6465-6474, https://doi.org/10.5194/acp11-6465-2011, $2011 \mathrm{~b}$.

Paatero, P. and Tapper, U.: Positive matrix factorization: A non-negative factor model with optimal utilization of error estimates of data values, Environmetrics, 5, 111-126, https://doi.org/10.1002/env.3170050203, 1994.

Putero, D., Landi, T. C., Cristofanelli, P., Marinoni, A., Laj, P., Duchi, R., Calzolari, F., Verza, G. P., and Bonasoni, P.: Influence of open vegetation fires on black carbon and ozone variability in the southern Himalayas (NCO-P, 5079 m a.s.1.), Environ. Pollut., 184, 597-604, https://doi.org/10.1016/j.envpol.2013.09.035, 2014.

Raatikainen, T., Vaattovaara, P., Tiitta, P., Miettinen, P., Rautiainen, J., Ehn, M., Kulmala, M., Laaksonen, A., and Worsnop, D. R.: Physicochemical properties and origin of organic groups detected in boreal forest using an aerosol mass spectrometer, Atmos. Chem. Phys., 10, 2063-2077, https://doi.org/10.5194/acp10-2063-2010, 2010.

Ram, K., Sarin, M. M., and Hegde, P.: Long-term record of aerosol optical properties and chemical composition from a highaltitude site (Manora Peak) in Central Himalaya, Atmos. Chem. Phys., 10, 11791-11803, https://doi.org/10.5194/acp-10-117912010, 2010.

Ramanathan, V. and Carmichael, G.: Global and regional climate changes due to black carbon, Nature Geoscience, 1, 221-227, https://doi.org/10.1038/ngeo156, 2008.

Saarikoski, S., Carbone, S., Decesari, S., Giulianelli, L., Angelini, F., Canagaratna, M., Ng, N. L., Trimborn, A., Facchini, M. C., Fuzzi, S., Hillamo, R., and Worsnop, D.: Chemical characterization of springtime submicrometer aerosol in Po Valley, Italy, Atmos. Chem. Phys., 12, 8401-8421, https://doi.org/10.5194/acp12-8401-2012, 2012.

Sun, Y. L., Zhang, Q., Macdonald, A. M., Hayden, K., Li, S. M., Liggio, J., Liu, P. S. K., Anlauf, K. G., Leaitch, W. R., Steffen, A., Cubison, M., Worsnop, D. R., van Donkelaar, A., and Martin, R. V.: Size-resolved aerosol chemistry on Whistler Mountain, Canada with a high-resolution aerosol mass spec- trometer during INTEX-B, Atmos. Chem. Phys., 9, 3095-3111, https://doi.org/10.5194/acp-9-3095-2009, 2009.

Sun, Y. L., Zhang, Q., Schwab, J. J., Chen, W. N., Bae, M. S., Hung, H. M., Lin, Y. C., Ng, N. L., Jayne, J., Massoli, P., Williams, L. R., and Demerjian, K. L.: Characterization of near-highway submicron aerosols in New York City with a high-resolution aerosol mass spectrometer, Atmos. Chem. Phys., 12, 2215-2227, https://doi.org/10.5194/acp-12-2215-2012, 2012.

Sun, Y. L., Wang, Z., Fu, P., Jiang, Q., Yang, T., Li, J., and Ge, X.: The impact of relative humidity on aerosol composition and evolution processes during wintertime in Beijing, China, Atmos. Environ., 77, 927-934, https://doi.org/10.1016/j.atmosenv.2013.06.019, 2013.

Sun, Y., Du, W., Fu, P., Wang, Q., Li, J., Ge, X., Zhang, Q., Zhu, C., Ren, L., Xu, W., Zhao, J., Han, T., Worsnop, D. R., and Wang, Z.: Primary and secondary aerosols in Beijing in winter: sources, variations and processes, Atmos. Chem. Phys., 16, 8309-8329, https://doi.org/10.5194/acp-16-8309-2016, 2016.

Takami, A., Miyoshi, T., Shimono, A., and Hatakeyama, S.: Chemical composition of fine aerosol measured by AMS at Fukue Island, Japan during APEX period, Atmos. Environ., 39, 49134924, https://doi.org/10.1016/j.atmosenv.2005.04.038, 2005.

Ulbrich, I. M., Canagaratna, M. R., Zhang, Q., Worsnop, D. R., and Jimenez, J. L.: Interpretation of organic components from Positive Matrix Factorization of aerosol mass spectrometric data, Atmos. Chem. Phys., 9, 2891-2918, https://doi.org/10.5194/acp-92891-2009, 2009.

Wan, X., Kang, S., Li, Q., Rupakheti, D., Zhang, Q., Guo, J., Chen, P., Tripathee, L., Rupakheti, M., Panday, A. K., Wang, W., Kawamura, K., Gao, S., Wu, G., and Cong, Z.: Organic molecular tracers in the atmospheric aerosols from Lumbini, Nepal, in the northern Indo-Gangetic Plain: influence of biomass burning, Atmos. Chem. Phys., 17, 8867-8885, https://doi.org/10.5194/acp17-8867-2017, 2017.

Wang, J., Ge, X., Chen, Y., Shen, Y., Zhang, Q., Sun, Y., Xu, J., Ge, S., Yu, H., and Chen, M.: Highly time-resolved urban aerosol characteristics during springtime in Yangtze River Delta, China: insights from soot particle aerosol mass spectrometry, Atmos. Chem. Phys., 16, 9109-9127, https://doi.org/10.5194/acp16-9109-2016, 2016a.

Wang, J., Onasch, T. B., Ge, X., Collier, S., Zhang, Q., Sun, Y., Yu, H., Chen, M., Prévôt, A. S. H., and Worsnop, D. R.: Observation of Fullerene Soot in Eastern China, Environ. Sci. Technol. Lett., 3, 121-126, https://doi.org/10.1021/acs.estlett.6b00044, 2016b.

Wang, J., Zhang, Q., Chen, M., Collier, S., Zhou, S., Ge, X., Xu, J., Shi, J., Xie, C., Hu, J., Ge, S., Sun, Y., and Coe, H.: First Chemical Characterization of Refractory Black Carbon Aerosols and Associated Coatings over the Tibetan Plateau (4730 m a.s.1.), Environ. Sci. Technol., 51, 14072-14082, https://doi.org/10.1021/acs.est.7b03973, 2017.

Wang, Y., Hu, M., Lin, P., Guo, Q., Wu, Z., Li, M., Zeng, L., Song, Y., Zeng, L., Wu, Y., Guo, S., Huang, X., and He, L.: Molecular Characterization of Nitrogen-Containing Organic Compounds in Humic-like Substances Emitted from Straw Residue Burning, Environ. Sci. Technol., 51, 5951-5961, https://doi.org/10.1021/acs.est.7b00248, 2017.

Wu, G., Liu, Y., Zhang, Q., Duan, A., Wang, T., Wan, R., Liu, X., Li, W., Wang, Z., and Liang, X.: The Influence of Mechanical and Thermal Forcing by the Tibetan Plateau on Asian Climate, J. 
Hydrometeorol., 8, 770-789, https://doi.org/10.1175/jhm609.1, 2007.

Xia, X., Zong, X., Cong, Z., Chen, H., Kang, S., and Wang, P.: Baseline continental aerosol over the central Tibetan plateau and a case study of aerosol transport from South Asia, Atmos. Environ., 45, 7370-7378, https://doi.org/10.1016/j.atmosenv.2011.07.067, 2011.

Xu, B., Cao, J., Hansen, J., Yao, T., Joswia, D. R., Wang, N., Wu, G., Wang, M., Zhao, H., Yang, W., Liu, X., and He, J.: Black soot and the survival of Tibetan glaciers, P. Natl. Acad. Sci. USA, 106, 22114-22118, https://doi.org/10.1073/pnas.0910444106, 2009.

Xu, J., Zhang, Q., Chen, M., Ge, X., Ren, J., and Qin, D.: Chemical composition, sources, and processes of urban aerosols during summertime in northwest China: insights from high-resolution aerosol mass spectrometry, Atmos. Chem. Phys., 14, 1259312611, https://doi.org/10.5194/acp-14-12593-2014, 2014.

Xu, J., Shi, J., Zhang, Q., Ge, X., Canonaco, F., Prévôt, A. S. H., Vonwiller, M., Szidat, S., Ge, J., Ma, J., An, Y., Kang, S., and Qin, D.: Wintertime organic and inorganic aerosols in Lanzhou, China: sources, processes, and comparison with the results during summer, Atmos. Chem. Phys., 16, 14937-14957, https://doi.org/10.5194/acp-16-14937-2016, 2016.

Xu, J., Zhang, Q., Shi, J., Ge, X., Xie, C., Wang, J., Kang, S., Zhang, R., and Wang, Y.: Chemical characteristics of submicron particles at the central Tibetan Plateau: insights from aerosol mass spectrometry, Atmos. Chem. Phys., 18, 427-443, https://doi.org/10.5194/acp-18-427-2018, 2018.

$\mathrm{Xu}$, L., Suresh, S., Guo, H., Weber, R. J., and Ng, N. L.: Aerosol characterization over the southeastern United States using high-resolution aerosol mass spectrometry: spatial and seasonal variation of aerosol composition and sources with a focus on organic nitrates, Atmos. Chem. Phys., 15, 7307-7336, https://doi.org/10.5194/acp-15-7307-2015, 2015.

Yadav, I. C., Devi, N. L., Li, J., Syed, J. H., Zhang, G., and Watanabe, H.: Biomass burning in Indo-China peninsula and its impacts on regional air quality and global climate change - a review, Environ. Pollut., 227, 414-427, https://doi.org/10.1016/j.envpol.2017.04.085, 2017.

Yang, K., Wu, H., Qin, J., Lin, C., Tang, W., and Chen, Y.: Recent climate changes over the Tibetan Plateau and their impacts on energy and water cycle: A review, Global Planet. Change, 112, 79-91, https://doi.org/10.1016/j.gloplacha.2013.12.001, 2014.

Yao, T., Thompson, L., Mosbrugger, V., Zhang, F., Ma, Y., Luo, T., Xu, B., Yang, X., Joswiak, D. R., Wang, W., Joswiak, M. E., Devkota, L. P., Tayal, S., Jilani, R., and Fayziev, R.: Third Pole Environment (TPE), Environ. Dev., 3, 52-64, https://doi.org/10.1016/j.envdev.2012.04.002, 2012a.

Yao, T., Thompson, L., Yang, W., Yu, W., Gao, Y., Guo, X., Yang, X., Duan, K., Zhao, H., Xu, B., Pu, J., Lu, A., Xiang, Y., Kattel, D. B., and Joswiak, D.: Different glacier status with atmospheric circulations in Tibetan Plateau and surroundings, Nat. Clim. Change, 2, 663-667, https://doi.org/10.1038/nclimate1580, 2012b.

Zhang, Q., Alfarra, M. R., Worsnop, D. R., Allan, J. D., Coe, H., Canagaratna, M. R., and Jimenez, J. L.: Deconvolution and quantification of hydrocarbon-like and oxygenated organic aerosols based on aerosol mass spectrometry, Environ. Sci. Technol., 39, 4938-4952, https://doi.org/10.1021/es0485681, 2005a.
Zhang, Q., Canagaratna, M. R., Jayne, J. T., Worsnop, D. R., and Jimenez, J. L.: Time- and size-resolved chemical composition of submicron particles in Pittsburgh: Implications for aerosol sources and processes, J. Geophys. Res., 110, D07S09, https://doi.org/10.1029/2004jd004649, 2005b.

Zhang, Q., Jimenez, J. L., Canagaratna, M. R., Allan, J. D., Coe, H., Ulbrich, I., Alfarra, M. R., Takami, A., Middlebrook, A. M., Sun, Y. L., Dzepina, K., Dunlea, E., Docherty, K., DeCarlo, P. F., Salcedo, D., Onasch, T., Jayne, J. T., Miyoshi, T., Shimono, A., Hatakeyama, S., Takegawa, N., Kondo, Y., Schneider, J., Drewnick, F., Borrmann, S., Weimer, S., Demerjian, K., Williams, P., Bower, K., Bahreini, R., Cottrell, L., Griffin, R. J., Rautiainen, J., Sun, J. Y., Zhang, Y. M., and Worsnop, D. R.: Ubiquity and dominance of oxygenated species in organic aerosols in anthropogenically-influenced Northern Hemisphere midlatitudes, Geophys. Res. Lett., 34, L13801, https://doi.org/10.1029/2007g1029979, 2007a.

Zhang, Q., Jimenez, J. L., Worsnop, D. R., and Canagaratna, M.: A case study of urban particle acidity and its influence on secondary organic aerosol, Environ. Sci. Technol., 41, 3213-3219, https://doi.org/10.1021/es061812j, 2007b.

Zhang, Q., Jimenez, J. L., Canagaratna, M. R., Ulbrich, I. M., Ng, N. L., Worsnop, D. R., and Sun, Y.: Understanding atmospheric organic aerosols via factor analysis of aerosol mass spectrometry: a review, Anal. Bioanal. Chem., 401, 3045-3067, https://doi.org/10.1007/s00216-011-5355-y, 2011.

Zhang, R., Wang, Y., He, Q., Chen, L., Zhang, Y., Qu, H., Smeltzer, C., Li, J., Alvarado, L. M. A., Vrekoussis, M., Richter, A., Wittrock, F., and Burrows, J. P.: Enhanced trans-Himalaya pollution transport to the Tibetan Plateau by cut-off low systems, Atmos. Chem. Phys., 17, 3083-3095, https://doi.org/10.5194/acp17-3083-2017, 2017.

Zhang, X., Zhang, Y., Sun, J., Yu, Y., Canonaco, F., Prevot, A. S., and Li, G.: Chemical characterization of submicron aerosol particles during wintertime in a northwest city of China using an Aerodyne aerosol mass spectrometry, Environ. Pollut., 222, 567582, https://doi.org/10.1016/j.envpol.2016.11.012, 2017.

Zhao, Z., Cao, J., Shen, Z., Xu, B., Zhu, C., Chen, L. W. A., Su, X., Liu, S., Han, Y., Wang, G., and Ho, K.: Aerosol particles at a high-altitude site on the Southeast Tibetan Plateau, China: Implications for pollution transport from South Asia, J. Geophys. Res.Atmos., 118, 11360-11375, https://doi.org/10.1002/jgrd.50599, 2013.

Zheng, J., Hu, M., Du, Z., Shang, D., Gong, Z., Qin, Y., Fang, J., Gu, F., Li, M., Peng, J., Li, J., Zhang, Y., Huang, X., He, L., Wu, Y., and Guo, S.: Influence of biomass burning from South Asia at a high-altitude mountain receptor site in China, Atmos. Chem. Phys., 17, 6853-6864, https://doi.org/10.5194/acp17-6853-2017, 2017.

Zhou, S., Collier, S., Jaffe, D. A., Briggs, N. L., Hee, J., Sedlacek Iii, A. J., Kleinman, L., Onasch, T. B., and Zhang, Q.: Regional influence of wildfires on aerosol chemistry in the western US and insights into atmospheric aging of biomass burning organic aerosol, Atmos. Chem. Phys., 17, 2477-2493, https://doi.org/10.5194/acp-17-2477-2017, 2017. 
Zhu, Q., He, L. Y., Huang, X. F., Cao, L. M., Gong, Z. H., Wang, C., Zhuang, X., and Hu, M.: Atmospheric aerosol compositions and sources at two national background sites in northern and southern China, Atmos. Chem. Phys., 16, 10283-10297, https://doi.org/10.5194/acp-16-10283-2016, 2016.
Zou, H., Zhou, L., Ma, S., Li, P., Wang, W., Li, A., Jia, J., and Gao, D.: Local wind system in the Rongbuk Valley on the northern slope of Mt. Everest, Geophys. Res. Lett., 35, L13813, https://doi.org/10.1029/2008g1033466, 2008. 